PILOT PLANT NITRIC ACID RECOVERY BY DISTILLATION OF CONDENSATE WASTE

E. G. Laggis 


\section{DISCLAIMER}

This report was prepared as an account of work sponsored by an agency of the United States Government. Neither the United States Government nor any agency Thereof, nor any of their employees, makes any warranty, express or implied, or assumes any legal liability or responsibility for the accuracy, completeness, or usefulness of any information, apparatus, product, or process disclosed, or represents that its use would not infringe privately owned rights. Reference herein to any specific commercial product, process, or service by trade name, trademark, manufacturer, or otherwise does not necessarily constitute or imply its endorsement, recommendation, or favoring by the United States Government or any agency thereof. The views and opinions of authors expressed herein do not necessarily state or reflect those of the United States Government or any agency thereof. 


\section{DISCLAIMER}

Portions of this document may be illegible in electronic image products. Images are produced from the best available original document. 
Reference to a company or product name does not imply approval or recommendation of the product by Union Carbide Corporation or the U.S. Atomic Energy Commission to the exclusion of others that may meet specifications.

Printed in the United States of America. Available from

National Technical Information Service

U.S. Department of Commerce

5285 Port Royal Road, Springfield, Virginia 22151

Price: Printed Copy $\$ 4.00 ;$ Microfiche $\$ 1.45$

This report was prepared as an account of work sponsored by the United States Government. Neither the United States nor the United States Atomic Energy Commission, nor any of their employees, nor any of their contractors, subcontractors, or their employees, makes any warranty, express or implied, or assumes any legal liability or responsibility for the accuracy, completeness or usefulness of any information, apparatus, product or process disclosed, or represents that its use would not infringe privately owned rights. 


\title{
PILOT PLANT NITRIC ACID RECOVERY BY DISTILLATION OF CONDENSATE WASTE
}

\author{
E. G. Laggis
}

Materials Engineering Development

Y-12 Development Division

their contractors, subcontractors, or their employees,

makes any warranty, express or implied, or assumes any

legal liability or responsibility for the accuracy, com-

pleteness or usefulness of any information, apparatus,

product or process disclosed, or represents that its use

would nat infringe privately owned rights.

Oak Ridge Y-12 Plant

P.O. Box Y, Oak Ridge, Tènnessee 37830

Prepared for the U.S. Atomic Energy Commission

Under U.S. Buvernilitil Cullidal $W=7405$ ély.26 


\begin{abstract}
A nitric acid distillation pilot plant was operated in support of a plant effort to recycle part of the nitrate effluents leaving the plant. Optimum operating conditions, distribution of chlorides and fluorides, effectiveness of a fluoride trap, and distillation performance were defined in test runs using anion-spiked nitric acid as a feed solution.

The pilot plant was also operated continuously in a 15-day campaign to convert condensate waste from the uranium purification process to concentrated nitric acid. The impact of uranium, chloride, fluoride, and organic impurities in the waste on engineering design, operation, and recovered acid quality was evaluated from the derived pilot plant data supplemented with laboratory tests. Problem areas were revealed regarding feed impurities in the nitric acid product and organic reactions which had not occurred in all previous work using synthetic feed solutions. In addition to an evaluation of the nitric acid recovery performance, composition of the system output streams, and product quality, corrosion field tests were made for recommending materials of construction of a plant.
\end{abstract}


CONTENTS

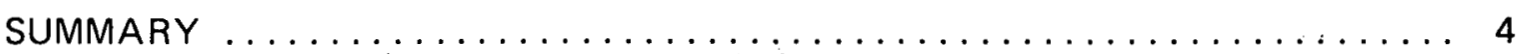

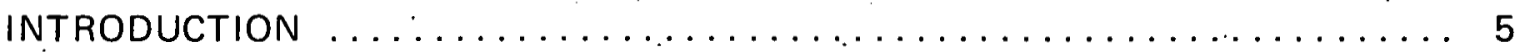

NITRIC ACID RECOVERY FROM CONDENSATE WASTE $\ldots \ldots \ldots \ldots \ldots \ldots \ldots 7$

Experimental Program ............................ 7

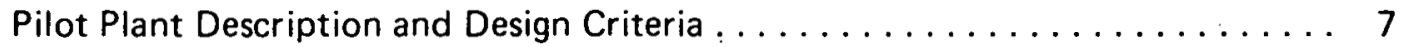

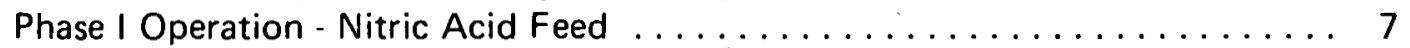

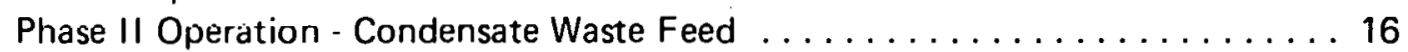

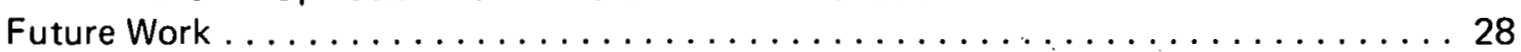

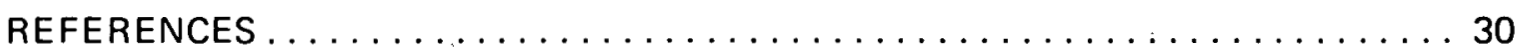




\section{SUMMARY}

Test runs were initially made in the distillation pilot plant to define the operating conditions for concentrating 1.5 to 3.2-molar nitric acid spiked with $90 \mu \mathrm{g} / \mathrm{g}$ chlorides and fluorides. Vapor feed at a $22.5 \mathrm{I} / \mathrm{hr}$ liquid flow rate of 1.5 -molar acid to the four-inch packed column, at a reflux ratio of 0.33 , yielded 13.4-molar product and a water distillate containing 281 $\mu \mathrm{g} / \mathrm{g}$ nitrate. About $70 \mathrm{wt} \%$ of the chloride input was removed with the distillate, but chloride buildup to $170 \mu \mathrm{g} / \mathrm{g}$ occurred at and below the midcolumn feed point, and the nitric acid product contained $30 \mu \mathrm{g} / \mathrm{g}$ chloride. A fluoride trap of aluminum nitrate and calcium nitrate proved to be effective in limiting the fluoride input to the column and, consequently, reducing the product fluoride from 200 to $6 \mu \mathrm{g} / \mathrm{g}$.

The pilot plant was then operated continuously using actual condensate waste from the uranium purification operation. This condensate waste was converted into a 13.4-molar nitric acid product and a water distillate having a pH of 2.3. Chloride and fluoride impurities concentrated in the product, contrary to previous work using the synthetic feed solution. Kerosene extraction of dissolved organics from the waste stream was ineffective in removing the cause of apparent trace organic/nitric acid reactions in two isolated incidents. Extraction reduced the organic carbon in the feed from 540 to $320 \mu \mathrm{g} / \mathrm{g}$; subsequent adsorption with activated carbon in a laboratory test reduced the carbon level to $33 \mu \mathrm{g} / \mathrm{g}$. Corrosion field tests were also made in the pilot plant for selecting materials of construction. 


\section{INTRODUCTION}

A program is underway at the Oak Ridge $\mathrm{Y}-12$ Plant ${ }^{(a)}$ which is designed to ultimately curtail or eliminate the indirect release of acidic nitrate effluents into the Plant's ground water and stream environment. Essentially all Plant nitrate effluents are generated by uranium recovery processes as evaporator condensate and aluminum nitrate-type extraction raffinate. Recycling of the nitric acid by distillation from the evaporated condensate and from condensates produced by raffinate treatment processes has been proposed. In addition to low ( $1 \mu \mathrm{g} / \mathrm{g}$ or less) levels of enriched uranium, the condensate waste streams contain chloride and fluoride impurities. These anions are known to concentrate in distillation systems at concentrations which are corrosive to stainless steel equipment.

A packed-tower-type distillation pilot plant was built to determine: (1) the capacity and performance data for engineering scaleup; (2) the chloride distribution and effectiveness of a developed fluoride trap mechanism, both relative to product purity; (3) degree of isolation of uranium from the tower; (4) corrosion resistance of candidate materials of construction, and (5) reactivity and impact on system performance of entrained and dissolved organics prevalent in the condensate waste solutions.

This report reviews the pilot plant and associated laboratory work conducted through calendar year 1973. Since the purpose of the work was to provide engineering design data, recommendations are embodied in those sections of the text which are titled to suit the particular design problem area. Phase I of the work deals with nitric acid distillation and anion distribution; Phase II presents the chemical effects of the condensate waste that are imposed on the system design.

The National Lead Company of Ohio has had experience in operating a nitric acid recovery facility at their Fernald uranium refinery. (1) Extraction raffinates were evaporated and the overhead vapor was distilled in a bubble-cap-type column to produce a bottoms product of 55 to $60 \mathrm{wt} \%$ nitric acid. Test operation of the plant-scale system ${ }^{(2)}$ showed that chloride concentrated or accumulated at the column's midpoint, as anticipated from a process engineering study. (3) An ozone reaction unit was used on a sidestream from the column at the midpoint to remove chlorides as a control on chloride levels in the stainless steel column. Fluoride buildup in the column was held to $150 \mu \mathrm{g} / \mathrm{g}$ or less by minimizing the fluoride input to the columir. This restriction was accomplished by adding the aluminum ion to the raffinate stream (at a $5: 1 \mathrm{Al} / \mathrm{F}$ weight ratio) to complex the fluoride and suppress its volatility from the evaporator. The published data $(2)$ show 1.5 to $9 \mu \mathrm{g} / \mathrm{g} \mathrm{Cl}^{-}$and 11 and 48 $\mu \mathrm{g} / \mathrm{g} \mathrm{F}^{-}$in the 48 to $63 \mathrm{wt} \%$ acid product. Rather frequent shutdowns (every 5 to 6 weeks) were scheduled to inspect for corrosion attack and make repairs. Vacuum operation was recommended $(2)$ to reduce the column operating temperature and, therefore, the corrosion rates.

Fernald data ${ }^{(2)}$ were utilized in a 1958 Y -12 report ${ }^{(4)}$ dealing with corrosive failure of a Plant acid distillation system. Reduced pressure and operating conditions were proposed to

(a) Operated by the Union Carbide Corporation's Nuclear Division for the US Atomic Energy Commission. 
minimize chloride and fluoride buildup in the column. The conditions involved accepting a less concentrated acid product $(38 \%)$ or a low acid recovery $(58 \%)$.

Current $Y-12$ interest in recovering nitric acid prompted laboratory-scale studies $(5)$ by using a packed column to concentrate dilute acid feed spiked with up to $400 \mu \mathrm{g} / \mathrm{g}$ of the chloride and fluoride anions. Chlorides concentrated at or above the midcolumn feed point, but were removed in the distillate at a level about equal to the feed. The bottoms product contained very low chloride. In contrast, the fluoride moved down the column and contaminated the product.

Laboratory studies(5) were then directed toward minimizing the fluoride entry to a distillation system by removing the fluoride from a dilute acid feed solution. This action was accomplished by utilizing the fluoride complexing ability of aluminum nitrate in a fluoride-trap concept. A trap media consisting of the nitrates of molten calcium and aluminum was shown to be capable of retaining fluoride from a liquid nitric acid feed conlaining $400 \mu \mathrm{y} / \mathrm{y} \mathrm{F}^{=}$while pruducing. a vajuir containing a nitrie acid molarity that is equal to the feed, but only with a few ppm of fluoride. The ratio of calcium and aluminum in the trap media was studied in reference to the acid/feed content and trap fluoride output. 


\section{NITRIC ACID RECOVERY FROM CONDENSATE WASTE}

\section{EXPERIMENTAL PROGRAM}

\section{Pilot Plant Description and Design Criteria}

The pilot-plant system consisted of an all-glass, packed-column-type distillation assembly commercially supplied as an integral unit, $(b)$ as outlined in Figure 1 . The unit was built in compliance with $Y-12$ process design information $(6)$ to convert $8 \mathrm{gal} / \mathrm{hr}(8.4 \mathrm{E}-06 \mathrm{~m} 3 / \mathrm{s})$, maximum, of $10 \mathrm{wt} \%$ acid feed to $68 \mathrm{wt} \% \mathrm{HNO}_{3}$ and a water distillate using available 50-psig (345-kPa) saturated steam and $85^{\circ} \mathrm{F}(302 \mathrm{~K})$ cooling water. Maximum vapor velocity (superficial) in the enriching section was specified as $5 \mathrm{ft} / \mathrm{sec}(1.5 \mathrm{~m} / \mathrm{s})$. There was one column feed point located at the midpoint (between Sections 3 and 4, Figure 1). There were three 4 -inch by 30 -inch column sections packed with $1 / 2$-inch ceramic Intalox saddles above and below the feed point. The column also had provisions for sampling the vapor entering the three rectifying sections (V-4, V-5, and V-6). A reflux divider was inserted between Sections 2 and 3, where the $\mathrm{Cl}^{-}$and $\mathrm{F}^{-}$were anticipated to concentrate, to permit withdrawing and returning a liquid sidestream. The divider unit was also used to provide the only vapor and liquid samples (V-3 and L-3) in the stripping portion of the column. The column system was supplemented with a vertical-tube, stainless steel heat exchanger in series with the preheater to give sufficient heat for vapor feeding the column. A mesh-type deentrainment pot topped the vaporizer to potentially exclude any uranium carry over into the column. The uranium concentrated in the aluminum nitrate/calcium nitrate liquid vaporizer system, which also served as a chemical trap for fluoride ions which were present in the liquid feed. The vapor feed mode and vaporizer performance were, therefore, key factors in producing reusable nitric acid.

System temperatures were read from thermometers in the reboiler (T-R), in the stripping section (T-1), at and slightly above the feed pipe (T-3), in the vapor entering the condenser (T-6), and in the liquid or vapor flow through the preheater (T-F). In the vapor feed mode, the preheater was run with full steam pressure to revaporize feed that condensed in the lines. A thermometer was later placed on the shell side (steam) of the vaporizer to detect steam flow stoppage to the vaporizer.

A feed pump and retention vessels for feed, product, and distillate completed the pilot plant operating components. The entire system was originally built of nuclear-safe geometry: however, boron-glass-packed drums were substituted for the safe-bottle feed and distillate containers to facilitate initial operation using uranium-free water and nitric acid feed solutions. With suitable procedure limitations, the packed drums were later approved for condensate waste feed which characteristically contains $<1 \mu \mathrm{g} / \mathrm{g}$ enriched uranium.

\section{Phase I Operation - Nitric Acid Feed}

Following mechanical and leak testing of the system using water as a feed, a series of 14 six-hour operational runs (Table 1) were made to: (1) verify the designed capacity;

(b) Corning Glass Works, Corning, New York. 


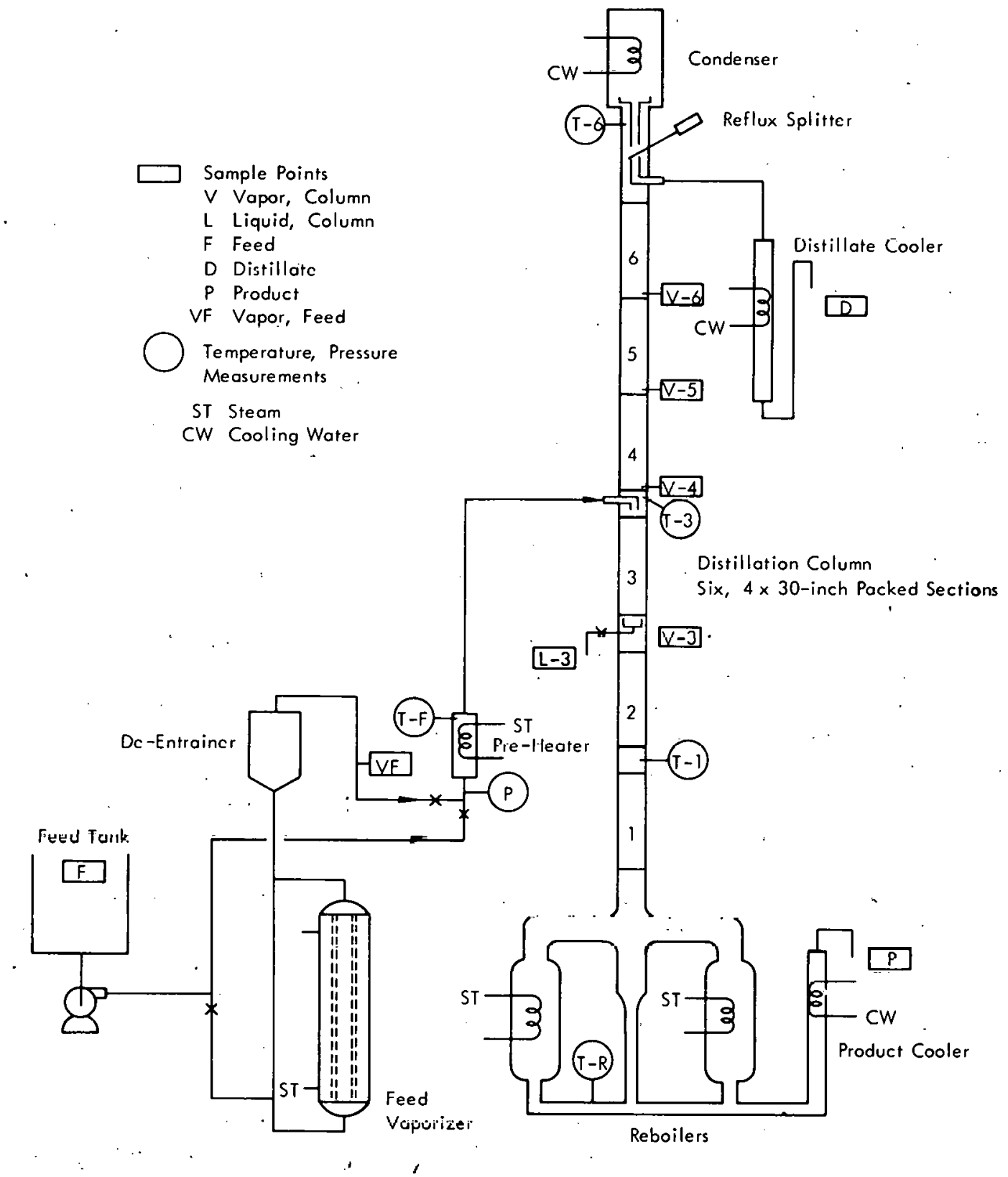

-Figure 1. NITRIC ACID RECOVERY PILOT PLANT. (Components and Data Source Points)

(2) establish the optimum, vapor feed operating conditions to yield a concentrated $\geqslant 60 \mathrm{wt}$ $\% \mathrm{HNO}_{3}$ ) product, but a high-pH distillate; (3) determine the conformance of chloride and fluoride distribution to laboratory results; (4) field test the mechanics (plugging and decomposition), and (5) ascertain the effectiveness of the developed chemical vaporizer trap.

The system exhibited excessive heat losses in early runs, and subnormal column temperatures condensed dilute acid in the stripping section. Consequently, it was not possible to concentrate the reboiler liquid using the maximum steam input to the reboilers. Attempts to operate at total reflux and sample the column for vapor/liquid composition 
Table 1

PILOT PLANT SHORT-RUN TESTS TO ESTABLISH OPERATING CONDITIONS

(Summary of Data Using Prepared Nitric Acid Spiked with HF. HCl as Feed).

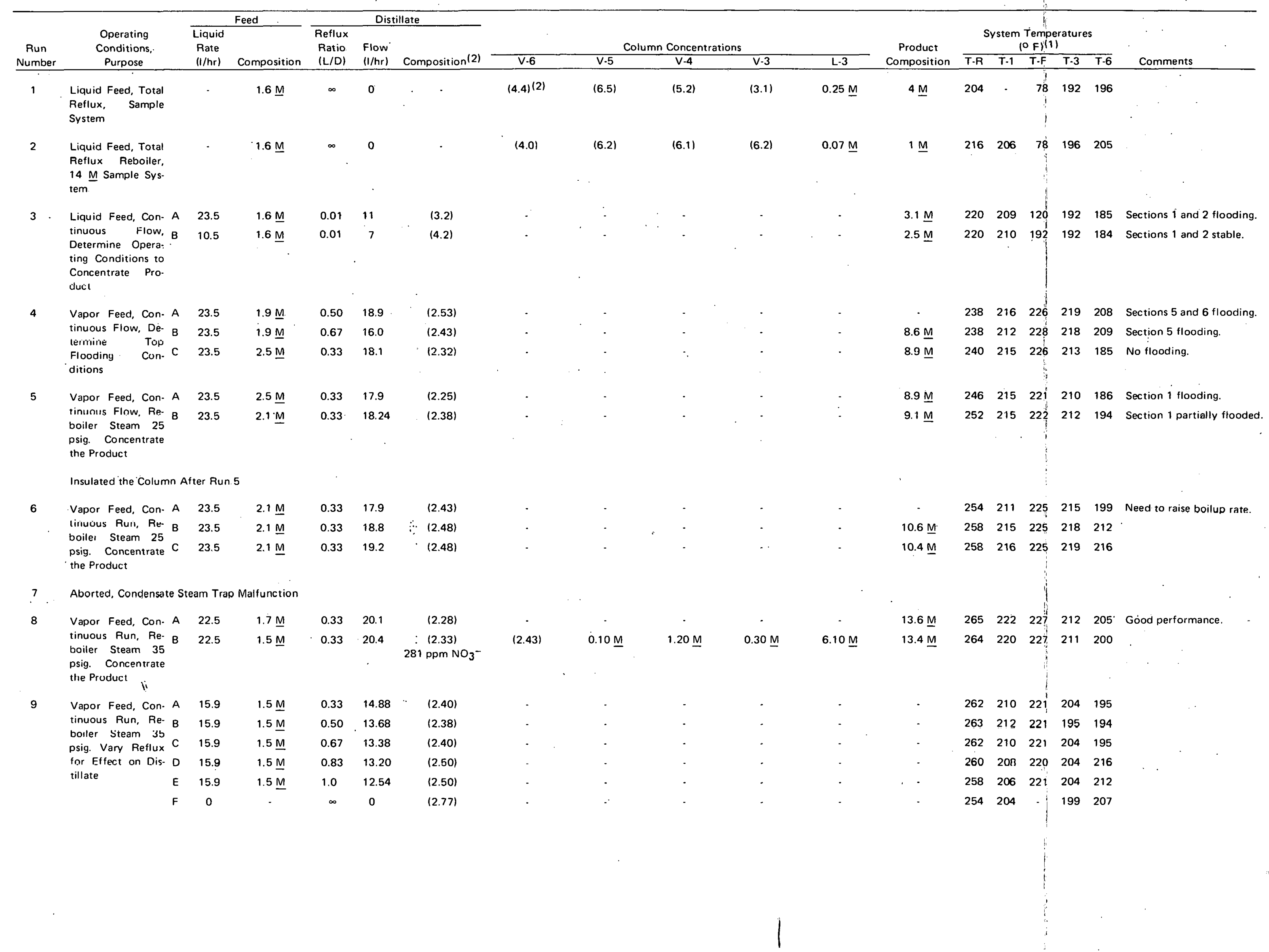


Table 1 (Continued).

\begin{tabular}{|c|c|c|c|c|c|c|c|c|c|c|c|c|c|c|c|c|c|c|c|}
\hline \multirow{3}{*}{$\begin{array}{c}\text { Run } \\
\text { Number }\end{array}$} & \multirow{3}{*}{\multicolumn{2}{|c|}{$\begin{array}{c}\text { Operating } \\
\text { Conditions, } \\
\text { Purpose } \\
\end{array}$}} & \multirow{3}{*}{$\begin{array}{l}\text { Liquid } \\
\text { Rate } \\
(\mathrm{I} / \mathrm{hr}) \\
\end{array}$} & \multirow{3}{*}{$\begin{array}{l}\text { Feed } \\
\text { Composition }\end{array}$} & \multirow{3}{*}{$\begin{array}{l}\text { Reflux } \\
\text { Ratio } \\
\text { (L/D) } \\
\end{array}$} & \multicolumn{2}{|c|}{ Distillate } & \multirow{2}{*}{\multicolumn{5}{|c|}{ Columin Concentrations }} & \multirow{3}{*}{$\begin{array}{c}\text { Product } \\
\text { Composition }\end{array}$} & \multirow{2}{*}{\multicolumn{5}{|c|}{$\begin{array}{c}\text { System Temperatures } \\
\left(\mathrm{O}^{\circ} \mathrm{F}\right)^{(1)}\end{array}$}} & \multirow{3}{*}{ Comments } \\
\hline & & & & & & \multirow{2}{*}{$\begin{array}{l}\text { Flow } \\
(1 / \mathrm{hr})\end{array}$} & \multirow[b]{2}{*}{ Composition (2) } & & & & & & & & & & & & \\
\hline & & & & & & & & $v-6$ & $\begin{array}{ll}\mathrm{V} .5 \\
\end{array}$ & $V-4$ & $\mathrm{~V}-3$ & $\mathrm{~L}-3$ & & $T \cdot R$ & $\mathrm{~T}-1$ & $T-F$ & $T-3$ & $T 6$ & \\
\hline 10 & \multicolumn{2}{|l|}{$\begin{array}{l}\text { Liquid Feed, Con- } \\
\text { tinuous Run, Re- } \\
\text { boiler Steam } 45 \\
\text { psig. Concentrate } \\
\text { the Product and } \\
\text { Sample System }\end{array}$} & 11.0 & $1.5 \underline{M}$ & 0.33 & 9.0 & $\begin{array}{c}(2.87) \\
55 \mathrm{ppm} \mathrm{NO}_{3}^{-}\end{array}$ & (2.94) & (2.89) & $(2.84)$ & $(1.98)$ & $1.2 \underline{M}$ & $9.5 \underline{M}$ & 254 & 205 & 211 & 197 & 192 & Insufficient heat input. \\
\hline \multirow[t]{2}{*}{11} & \multirow{2}{*}{\multicolumn{2}{|c|}{$\begin{array}{l}\text { Liquid Feed, De- } A \\
\text { termine } \mathrm{Cl}, \mathrm{F} \text { Dis- } \\
\text { tribution }\end{array}$}} & 11.0 & $\begin{array}{c}1.6 \underline{\mathrm{M}} \\
73 \mathrm{ppm} \mathrm{\textrm {Cl } ^ { - }} \\
\text { 90 pisiii } \mathrm{r}=\end{array}$ & 0.33 & 7.50 & $\begin{array}{c}(2.10) \\
367 \mathrm{ppm} \mathrm{NO}_{3}^{-} \\
99 \mathrm{ppm} \mathrm{\textrm {Cl } ^ { - }} \\
60.2 \mathrm{ppm} \mathrm{r}^{-}\end{array}$ & $\begin{array}{c}(2.10) \\
87 \mathrm{ppm} \mathrm{Cl}^{-} \\
0.35 \mathrm{ppin} \mathrm{r}^{-}\end{array}$ & $\begin{array}{c}(2.18) \\
76 \mathrm{ppm} \mathrm{Cl}^{-} \\
0.70 \mathrm{ppm} \mathrm{I}^{-}\end{array}$ & 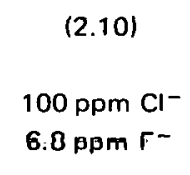 & 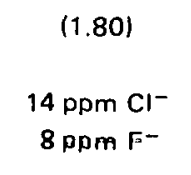 & 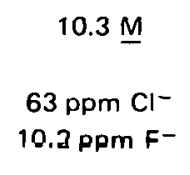 & 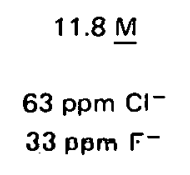 & 256 & 208 & 205 & 200 & 228 & \\
\hline & & & 11.0 & $\begin{array}{c}1.6 \underline{\mathrm{M}} \\
73 \mathrm{ppm} \mathrm{\textrm {Cl } ^ { - }} \\
90 \mathrm{ppm} \mathrm{F}^{-}\end{array}$ & 0.33 & 8.7 & $\begin{array}{c}(2.30) \\
176 \mathrm{ppm} \mathrm{NO}_{3}^{-} \\
63 \mathrm{ppm} \mathrm{\textrm {Cl } ^ { - }} \\
1.52 \mathrm{ppm} \mathrm{F} \mathrm{F}^{-}\end{array}$ & $\begin{array}{c}(2.75) \\
19 \mathrm{ppm} \mathrm{Cl}^{-} \\
0.23 \mathrm{ppm} \mathrm{F}-\end{array}$ & $\begin{array}{c}(2.35) \\
69 \mathrm{ppm} \mathrm{Cl}^{-} \\
0.74 \mathrm{ppm} \mathrm{F}^{-}\end{array}$ & $\begin{array}{c}(2.20) \\
97 \mathrm{ppm} \mathrm{Cl}^{-} \\
7.4 \mathrm{ppm} \mathrm{F}^{-}\end{array}$ & $\begin{array}{c}(1.8) \\
120 \mathrm{ppm} \mathrm{\textrm {Cl } ^ { - }} \\
8.2 \mathrm{ppm} \mathrm{F}\end{array}$ & $\begin{array}{c}4.20 \underline{\mathrm{M}} \\
87 \mathrm{ppm} \mathrm{Cl}^{-} \\
49 \mathrm{ppm} \mathrm{F}^{-}\end{array}$ & $\begin{array}{c}9.30 \mathrm{M} \\
20 \mathrm{ppm} \mathrm{Cl}^{-} \\
170 \mathrm{ppm} \mathrm{F}-\end{array}$ & 256 & 206 & 204 & 208 & 205 & \\
\hline \multirow[t]{2}{*}{12} & \multirow{2}{*}{$\begin{array}{l}\text { Vapor Feed, Con- } \\
\text { tinuous Run, Re- } \\
\text { boiler Steam } 35 \\
\text { psig. Determine Cl, } \\
\text { F Distribution }\end{array}$} & & 22.5 & $\begin{array}{c}2.25 \underline{\mathrm{M}} \\
87 \mathrm{ppm} \mathrm{Cl}^{-} \\
89 \mathrm{ppm} \mathrm{F}^{-}\end{array}$ & 0.33 & 20.7 & $\begin{array}{c}(1.90) \\
536 \mathrm{ppm} \mathrm{NO}_{3^{-}}^{-} \\
62 \mathrm{ppm} \mathrm{Cl}^{-} \\
2.54 \mathrm{ppm} \mathrm{F}^{-}\end{array}$ & $\begin{array}{c}(2.60) \\
27 \mathrm{ppm} \mathrm{C1}^{-} \\
12.2 \mathrm{ppm} \mathrm{F}^{-}\end{array}$ & $\begin{array}{c}(1.1) \\
111 \mathrm{ppm} \mathrm{Cl^{- }} \\
138 \mathrm{ppm} \mathrm{F}\end{array}$ & $\begin{array}{c}1.60 \underline{\mathrm{M}} \\
176 \mathrm{ppm} \mathrm{Cl}^{-} \\
1.1 \mathrm{ppm} \mathrm{F}\end{array}$ & $\begin{array}{c}0.80 \underline{\mathrm{M}} \\
113 \mathrm{ppm} \mathrm{Cl}^{-} \\
1.1 \mathrm{ppm} \mathrm{F}^{-}\end{array}$ & $\begin{array}{c}6.20 \underline{\mathrm{M}} \\
167 \mathrm{ppm} \mathrm{Cl}^{-} \\
230 \mathrm{ppm} \mathrm{F}^{-}\end{array}$ & 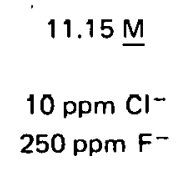 & 260 & 221 & 221 & 218 & 234 & . \\
\hline & & $B$ & 22.5 & 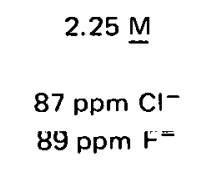 & 0.33 & $20.7^{\circ}$ & 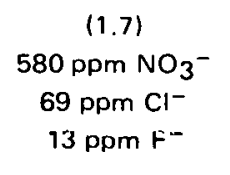 & 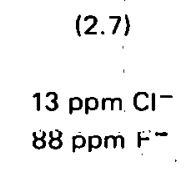 & 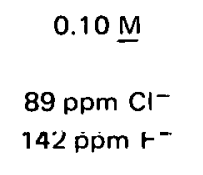 & 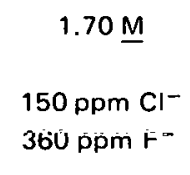 & 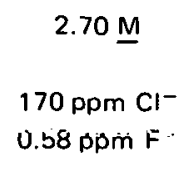 & 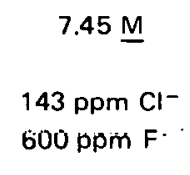 & $\begin{array}{c}13.65 \underline{\mathrm{M}} \\
30 \mathrm{ppm} \mathrm{Cl}^{-} \\
155 \mathrm{ppm} \mathrm{F}^{-\cdots}\end{array}$ & 266 & 232 & 222 & 212 & 192 & . \\
\hline 13 & $\begin{array}{l}\text { Vapor Feed, Conl- } \\
\text { rinuous Run, Re- } \\
\text { boiler Steam } 35 \\
\text { psig. Test Fluoride } \\
\text { Trap Mechanics. }\end{array}$ & & 22.5 & $3.2 \mathrm{M}$ & 0.33 & 19.0 & $(1.0)$ & $\cdot$ & - & . & - & - & $13.9 \mathrm{M}$ & 249 & 234 & 224 & 219 & 214 & $\begin{array}{l}\text { No vaporizer plugging } \\
\text { nroblems evidenreg. }\end{array}$ \\
\hline 14 & $\begin{array}{l}\text { Vapor Feed, Con- } \\
\text { tinuous Run, Re- } \\
\text { boiler Steam } 35 \\
\text { psig. Test Fluoride } \\
\text { Irap Mechanics. } \\
\text { Test Trop Fluoride } \\
\text { Removal Capa- } \\
\text { bility }\end{array}$ & & 22.5 & $\frac{2.0 \mathrm{M}}{34.6 \mathrm{ppm} \mathrm{F}^{-}}$ & 0.33 & 20.2 & (2.45) & $\begin{array}{l}\cdot \\
\vdots\end{array}$ & $<0.2 \mathrm{ppm} \mathrm{F-}$ & $\begin{array}{c}0.80 \mathrm{M} \\
1.68 \mathrm{ppm} \mathrm{F}^{-}\end{array}$ & $i$ & $\frac{7.7 \underline{M}}{18 \mathrm{ppm}^{-}}$ & $\frac{12.1 \mathrm{M}}{6.58 \mathrm{ppm} \mathrm{F-}}$ & $\therefore$ & . & . & - & - & $\begin{array}{l}\text { Fluoride trap performance } \\
\text { good. }\end{array}$ \\
\hline
\end{tabular}

1) Conversion factor to convert Fahrenheit temperatures to Kelvin degrees is $t_{K}=\left(t_{F}{ }^{0}+459.67\right) / 1.8$.

(2) Figures in paren theses denote $\mathrm{pH}$ value. 
comparisons with known equilibrium data resulted in an essentially water vapor composition extending into the stripping section (refer to Runs 1 and 2 of Table 1). The 1.6-molar $\mathrm{HNO}_{3}$ reboiler charge in Run 1 was concentrated to 4 molar under static, no-product withdrawal operating conditions. In Run 2, periodic input of 1.6-molar $\mathrm{HNO}_{3}$ feed resulted in dilution of the 14-molar reboiler charge, and a dilute product was withdrawn to prevent liquid buildup into the column stripping section.

Continuous-flow liquid-feed operations produced similar results (Run 3). Even at a very low reflux ratio $(0.01)$, distillate flow from a $23.5 \mathrm{I} / \mathrm{hr}(6.5 \mathrm{E}-06 \mathrm{~m} 3 / \mathrm{s})$ feed input of 1.6 -molar $\mathrm{HNO}_{3}$ was low by about a factor of 2 and the 3.1-molar product reflected dilution of the 14-molar reboiler charge with water condensation in the column. Control of the preheater steam input, to provide feed at its boiling point $\left[215^{\circ} \mathrm{F}(374 \mathrm{~K})\right]$, was found to be inadequate, although it was improved when the feed rate was reduced from 23.5 to $10.5 \mathrm{l} / \mathrm{hr}$ $(6.5$ to $2.92 \mathrm{E}-06 \mathrm{~m} 3 / \mathrm{s})$ in order to disengage the liquid that was flooding Sections 1 and 2 of the column.

Liquid-feed operation was temporarily abandoned in favor of the intended vapor-feed mode, which also augmented the system heat input and ultimately effected a successful system performance. The first vapor-feed run (Run 4) gave evidence that a $23.5 \mathrm{l} / \mathrm{hr}$ (6.53 E-06 $\mathrm{m} 3 / \mathrm{s}$ ) feed input affected the superficial vapor velocities in the upper column at or above the $5 \mathrm{ft} / \mathrm{sec}(1.524 \mathrm{~m} / \mathrm{s})$ design point. On startup at an L/D ratio equal to 0.50 , Column Sections 5 and 6 were visibly flooded. Liquid was being entrained into the condenser to account for the high $[18.9 \mathrm{l} / \mathrm{hr}(5.2 \mathrm{E}-06 \mathrm{~m} 3 / \mathrm{s})]$ distillate flow at this point. Vaporizer startup surges possibly contributed to the flooding conditions which were relieved by stopping the feed input. On resumption, at a decreased reboiler steam pressure but a higher $L / D$ ratio of 0.67 , incipient flooding in Section 5 was observed and distillate flow was 16.0 $1 / \mathrm{hr}(4.4 \mathrm{E}-06 \mathrm{~m} 3 / \mathrm{s})$ (Run 4B). Calculated vapor velocity at this point, using a water-vapor density of $26.7 \mathrm{lb} / \mathrm{ft}^{3}\left(427 \mathrm{~kg} / \mathrm{m}^{3}\right)$ was $4.94 \mathrm{ft} / \mathrm{sec}(1.5 \mathrm{~m} / \mathrm{s})$. The reflux ratio was then decreased to 0.33 , corresponding, to 1.5 times the calculated minimum reflux ratio to achieve rectification. At this value, top flooding of the column was eliminated and the data (Run 4C) gave a calculated vapor. velocity of $4.55 \mathrm{ft} / \mathrm{sec}(1.4 \mathrm{~m} / \mathrm{s}$ ), or $91 \%$ of the design maximum. These conditions $(23.5 \mathrm{l} / \mathrm{hr}$ feed and $0.33 \mathrm{~L} / D)$ were established as near the operating capacity for the ensuing vapor-feed operations. It was found that top flooding was detectable from the vapor-feed-line pressure gage which read $2,1.2$, and $0.5 \mathrm{psig}(13.8,8.3$, and $3.5 \mathrm{kPa}$ ) during the $A, B$, and $C$ portions of Run 4 , respectively. Thereafter, the top was never flooded at vapor-feed-line pressures of $<1$ psig $(<7 \mathrm{kPa})$. Column temperatures in Run 4 were noticeably, higher than in the liquid feed operation tests, and the $240^{\circ} \mathrm{F}$ $(389 \mathrm{~K})$, reboiler temperature reflected the moderately concentrated $(\sim 9 \mathrm{M})$ acid that was produced in spite of the system upsets.

Additional vapor feed runs were made to develop a reproducible set of operating conditions which would yield a concentrated reboiler product. The reboiler steam supply was fixed by regulating the supply pressure rather than by varying the steam flow at the maximum supply pressure. Reboiler steam input at $25 \mathrm{psig}(172 \mathrm{kPa})$ produced a 9-molar $\mathrm{HNO}_{3}$ product at a $23.5 \mathrm{I} / \mathrm{hr}(6.5 \mathrm{E}-06 \mathrm{~m} / \mathrm{s})$ feed rate of 2 to 2.5 -molar acid, and an L/D ratio of 0.33 . However, since there was liquid loading of Sections 1 and 2, it was decided to insulate the column and thereby eliminate the troublesome heat losses. The liquid phase was eliminated and a stronger (10.5 M) product was made in Run 6 at identical operating conditions. Increasing the reboiler steam to $35 \mathrm{psig}(241 \mathrm{kPa})$ yielded a 13.5 -molar acid product and established acceptable operating conditions (Run 8). There was no detectable flooding in 
the column. The distillate $\mathrm{pH}$ was 2.33 and analyzed $281 \mu \mathrm{g} / \mathrm{g} \mathrm{NO}_{3}{ }^{-}$, which was close to the $294 \mu \mathrm{g} / \mathrm{g}$ value calculated from the $\mathrm{pH}$ value.

The effect of an increased reflux on the distillate $\mathrm{pH}$ was explored (Run 9) at the same run conditions, but at decreased feed flows to prevent column top flooding. The decreased feed rate gave a higher distillate $\mathrm{pH}$ of 2.4. Step-wise increase of the reflux in the six-hour run to an $L / D$ ratio of 1 did not appreciably affect the distillate which had a pH of 2.50. At total reflux, the $\mathrm{pH}$ rose to 2.77 , equivalent to $107 \mu \mathrm{g} / \mathrm{g} \mathrm{NO}_{3}{ }^{-}$.

Nitric acid, chloride, and fluoride system compositions were derived in a return to liquid feed (Runs 10 and 11) and also by the optimized vapor-feed operating conditions (Run 12) with no difficulty. Finally, the physical stability and fluoride complexing effectiveness of a recommended (7) 31.3 wt \% $\left.\mathrm{AllNO}_{3}\right)_{3} \cdot 9 \cdot \mathrm{H}_{2} \mathrm{O}-68.7$ wt \% $\mathrm{Ca}\left(\mathrm{NO}_{3}\right)_{2} \cdot 4 \mathrm{H}_{2} \mathrm{O}$ molten salt trap were tested (Runs 13 and 14). It was necessary to dilute the salt solution with water prior to introducing it into the bottom piping of the vaporizer because it partially solidified when agitated. A stable solution having a density of $1.53 \mathrm{~g} / \mathrm{cm}^{3}\left(1.53 \mathrm{E}+03 \mathrm{~kg} / \mathrm{m}^{3}\right)$ was achieved by dilution. There was no evidence, as observed by an abnormal feed pump discharge pressure, that the nitrate salt was decomposing and plugging the vaporizer tubes during operation or on a second startup. The trap solution, when drained from the vaporizer, was liquid at a density of $1.34 \mathrm{~g} / \mathrm{cm}^{3}\left(1.34 \mathrm{E}+03 \mathrm{~kg} / \mathrm{m}^{3}\right)$. Its $3.75 \cdot 1$ iter $(3.75$ $\mathrm{E}-03 \mathrm{~m}^{3}$ ) volume indicated it to be diluted with the normal 2 liters $\left(2 \mathrm{E}-03 \mathrm{~m}^{3}\right)$ of vaporizer liquid holdup. A reliable operating procedure was evolved in the course of the 14 test runs. Run 7 was aborted due to a vaporizer steam trap malfunction and was therefore omitted from Table 1. Chemical data collected primarily in Runs 8 through 14 are discussed in the sections that follow.

Nitric Acid Distillation Performance - Operational test data from three pilot plant runs (Runs 8, 12, and 13) were used to compute the distillation performance data (Table 2) needed for the design of a production acid recovery system in addition to the system capacity, vapor flooding velocity, and other data already discussed. The three runs selected represent the preferred vapor-feed-type operation at established conditions to yield an acceptably concentrated product from feed of different acid contents. Since the runs were made at a fixed reflux ratio (L/D), the increased feed concentration caused higher distillate acid concentrations. Boilup rate, minimum $b_{\text {a }} / D$ required, and other pertinent data are given for the three feed concentrations used. The data were computed using a material balance and distillation equations, assuming a constant molal overflow. The molal heats of vaporization for water and nitric acid are 9729 and 7239 calories $(4.1$ and $3.0 \mathrm{E}+04 \mathrm{~J})$, respectively. The value for the $38.3 \mathrm{~mol} \%$ azeotrope (the most concentrated $\mathrm{HNO}_{3}$ component possible in the system) was estimated to be 8776 calories (3.7 E+04 J). A q value equal to zero was also used, which assumes feed entry as a saturated vapor. In view of the vaporizer-preheater arrangement and consistent vapor temperatures of $220^{\circ} \mathrm{F}(377 \mathrm{~K})$ for these runs, the assumption is considered legitimate.

The effect of an increased feed concentration decreased the measured distillate volume rate, since less of the water component was available as reflected in a decreased molar flow of enriching vapor, $V$, and a reduced flow of reflux, $L$. The product flow, therefore, increased from 2.5 to $5 \mathrm{l} / \mathrm{hr}\left(0.69\right.$ to $\left.1.4 \mathrm{E}-06 \mathrm{~m}^{3} / \mathrm{s}\right)$ since more of the acid component was entering the system and the distillate, although increasing to $\sim 0.1$-molar $\mathrm{HNO}_{3}$, was carrying very little of the acid input. 
Table 2

PILOT PLANT DISTILLATION PERFORMANCE DATA

(Data Summary for Selected Vapor-Feed Runs)

\begin{tabular}{|c|c|c|c|}
\hline & Run 8 & Run 12 & Run 13 \\
\hline \multicolumn{4}{|l|}{ Feed } \\
\hline$\underline{\mathrm{M}} \mathrm{HNO}_{3}$ & 1.5 & 2.25 & 3.20 \\
\hline$X_{f}, \mathrm{Mol}_{\% \mathrm{HNO}_{3}}$ & 2.749 & 4.16 & 5.989 \\
\hline $1 / h r(1)$ & 22.5 & 22.5 & 22.5 \\
\hline $\mathrm{mol} / \mathrm{hr} \mathrm{HNO}_{3}$ & 33.75 & 50.625 & 72.0 \\
\hline F, Total mol/hr & 1227.7 & 1216.9 & 1202.2 \\
\hline \multicolumn{4}{|l|}{ Distillate } \\
\hline$\underline{\mathrm{M}} \mathrm{HNO}_{3}$ & 0.0046 & 0.00921 & $\sim 0.1$ \\
\hline $\mathrm{X}_{\mathrm{d}} . \mathrm{Mol} \% \mathrm{HNO}_{3}$ & 0.008297 & 0.0167 & 0.181 \\
\hline $\mathrm{l} / \mathrm{hr}$ & 20.1 & 20.7 & 19.0 \\
\hline $\mathrm{mol} / \mathrm{hr} \mathrm{HNO}_{3}$ & 0.09246 & 0.1906 & 1.90 \\
\hline D, Total $\mathrm{mol} / \mathrm{hr}^{(2)}$ & 1120.9 & 1061.7 & 992.3 \\
\hline Product & & & \\
\hline$\underline{\mathrm{M}} \mathrm{HNO}_{3}$ & 13.4 & 13.65 & 13.90 \\
\hline$w t \% \mathrm{HNO}_{3}$ & 61.6 & 62.7 & 63.6 \\
\hline$X_{p}, \mathrm{Mol} \% \mathrm{HNO}_{3}$ & 31.5 & 32.5 & 33.4 \\
\hline $\mathrm{mol} / \mathrm{hr} \mathrm{HNO}_{3}(3)$ & 33.66 & 50.434 & 70.1 \\
\hline P, Total $\mathrm{mol} / \mathrm{hr}$ & 106.85 & 155.2 & 209.9 \\
\hline $1 / h r^{(4)}$ & 2.5 & 3.7 & 5.0 \\
\hline \multicolumn{4}{|l|}{ Reflux, Enriching Section } \\
\hline $\mathrm{L}, \quad(0.33 \mathrm{D}), \mathrm{mol} / \mathrm{hr}$ & 369.9 & 350.4 & 327.5 \\
\hline$V,(L+D), \mathrm{mol} / \mathrm{hr}$ & 1490.8 & 1412.1 & 1319.8 \\
\hline L/V Ratio & 0.248 & 0.248 & 0.248 \\
\hline Calculated $(5)$ Minimum L/D, $\mathrm{R}^{\prime}$ & 0.199 & 0.276 & 0.375 \\
\hline Actual L/D Used & 0.33 & 0.33 & 0.33 \\
\hline \multicolumn{4}{|l|}{ Reflux, Stripping Stectiun } \\
\hline$L^{\prime}, \quad(L$ for $q=0) \mathrm{mol} / \mathrm{hr}$ & 369.9 & 350.4 & 327.5 \\
\hline$V^{\prime},(V \cdot F$ for $q=0) \mathrm{mol} / \mathrm{hr}$ & 263.1 & 195.2 & 117.6 \\
\hline$L^{\prime} / V^{\prime}$ & 1.406 & 1.795 & 2.785 \\
\hline
\end{tabular}

(1) Conversion factor to obtain $\mathrm{m}^{3 / \mathrm{s}}$ can be oblained by multiplying by $3.6 \mathrm{E}-06$.

(2) By difference, F.P. Measured flow not accurate enough.

(3) By difference, $\mathrm{F}_{\mathrm{HNO}_{3}}-\mathrm{D}_{\mathrm{HNO}}$

(4) Calculated value. Reboiler overflow rate is meaningless in short run.

(5) Calculated from $R^{\prime}=X_{d}-Y_{i} / Y_{i} \cdot X_{i} \cdot X_{i}, Y_{i}$ determined from vapor-liquid equilibrium curve. Values used as follows:

\begin{tabular}{cllll}
\multirow{2}{*}{$\begin{array}{c}\text { Run } \\
\text { Number }\end{array}$} & \multicolumn{5}{c}{$\mathrm{HNO}_{3}(\mathrm{~mol} \%)$} \\
\cline { 2 - 5 } 8 & $\mathrm{X}_{\mathrm{f}}$ & $\mathrm{Y}_{\mathbf{i}}$ & \multicolumn{1}{c}{$\mathrm{X}_{\mathbf{d}}$} \\
\hline 8 & 2.749 & 16.9 & 2.8 & 0.0083 \\
12 & 4.16 & 19.9 & 4.3 & 0.0167 \\
13 & 5.989 & 22.2 & 0.2 & 0.181
\end{tabular}


Both the volumetric and molar flows of the product were calculated since actual product overflow from the reboiler was not important because it depended on the reboiler charge volume, slight changes in the column pressure which caused overflow surges, and other operating factors. The product molarity was measured by titration; and, in the course of a six-hour run, the reboiler charge of about 20 liters $\left(20 \mathrm{E}-03 \mathrm{~m}^{3}\right)$ was displaced at least once. The product concentration is quite accurate. The distillate molar flow, $D$, was also calculated by difference and the measured volume flow was not used. Due to the low molecular weight of water, small differences in flow yielded inaccurate results in material balances involving the product. Feed rates, composition, and product concentration measurements were, therefore, the bases for computation.

The minimum reflux ratio, $R^{\prime}$, was calculated to show the rectification ability of the packed-column system. ( $R^{\prime}$ values are dependent on the feed composition.) As the feed acid content increased, $R^{\prime}$ approached the constant reflux ratio of 0.33 which was used; but. in Run 13 , the ratio was slightly above 0.33 which is not possible and is explainable by some inaccuracy in the reflux splitter device. In other words, a $10 \mathrm{sec} / 30 \mathrm{sec}$ time setting does not correspond perfectly to a $10 / 30$ split of the overhead condensate. The point is that at near the minimum reflux operation in Runs 12 and 13 the distillate acid content rose, but not excessively. $R^{\prime}$ was calculated, as shown in the Table 2 footnote, using the actual measured values for the distillate acid composition, $X_{D}$. In order to accurately read the $X_{i}$ and $Y_{i}$ values, the $\mathrm{HNO}_{3}$ liquid/vapor equilibrium curve was plotted on two-directional probability paper. Values of ' $R$ ' necessary to provide distillate of low acid composition (as in Run 8) for high feed composition (as in Run 13) can be determined in the same way. The value of 0.33 was derived originally for a feed composition of $\sim 1.7$ molar and then multiplied by 1.5 , which is a standard method for a first approximation of the reflux ratio.

The derived stripping section data permits a rough evaluation of the pilot plant reboiler. Multiplying the vapor molar rate, $\mathrm{V}^{\prime}$, (Run 8 , Table 2 ) by the molal heat of vaporization $[8473 \mathrm{cal} / \mathrm{mol}(3.5 \mathrm{E}+04 \mathrm{~J} / \mathrm{mol})]$ and adding $40^{\circ} \mathrm{F}(277 \mathrm{~K})$ of sensible heat at 14.35 $\mathrm{cal} / \mathrm{mol}$-UF shows a heat demand of $2350 \mathrm{kcal} / \mathrm{hr}(2.7 \mathrm{E}+03 \mathrm{~J} / \mathrm{s})$. The vendor's data on the evaporator equipment indicate that each of the two reboilers are capable of transferring about $8000 \mathrm{kcal} / \mathrm{hr}(9.3 \mathrm{E}+03 \mathrm{~J} / \mathrm{s})$ using 35 to $50 \mathrm{psig}(2.4$ to $3.5 \mathrm{E}+05 \mathrm{~Pa}) \mathrm{steam}$. The reboiler heat supply was, therefore, adequate (at least for vapor feed operations), assuming proper steam-trap capacity and piping design.

Several McCabe-Thiele-type diagrams were constructed for the Run 8 data using vapor/liquid equilibrium plots to determine HETS. A value of 2 to $2.5 \mathrm{ft}(0.6$ to $0.8 \mathrm{~m})$ was derived. The pilot plant feed point appeared to be properly positioned (between the third and fourth theoretical stages).

Chloride Distribution - The system was operated on feed spiked with. 73 and $87 \mu \mathrm{g} / \mathrm{g} \mathrm{Cl}^{-}$ and $90 \mu \mathrm{g} / \mathrm{g} \mathrm{F}^{-}$to determine the distribution and buildup of these anions in the column, and particularly in the product. Although uranium process condensate wastes contain 10 or less $\mu \mathrm{g} / \mathrm{g}$ of these anions, high levels were used to facilitate detection and also to simulate the higher levels $(50 \mu \mathrm{g} / \mathrm{g})$ expected in acid wastes from evaporation or calcination of raffinate wastes. Two sets of samples were taken across the system in each operation using liquid and vapor feed modes (Runs 11 and 12, respectively). Data compiled at the end of each test (Runs $11 \mathrm{~B}$ and 12B, Table 1) more likely represent steady-state conditions. 
Chloride buildup to 120 and $170 \mu \mathrm{g} / \mathrm{g}$ was detected in the column; but, at the same time, $70 \%$ of the bulk chloride input was removed in the high-volume distillate stream at concentrations approximating the feed. The 9.30 and 13.65 -molar products were contaminated with 20 and $30 \mu \mathrm{g} / \mathrm{g} \mathrm{Cl}^{-}$, respectively, in the liquid and vapor feed (Runs 11B and 12B). There was no obvious advantage between the liquid and vapor feed mode regarding chloride distribution. Column vapor contained higher chloride at and below the feed point (Samples V-4 and V-3, Runs 11B and 12B); and, in general, decreased in moving up the column in accordance with other work (8). correlating chloride volatility with increasing nitric acid composition. A measure of chloride volatility $\left(\mathrm{Y}_{\mathrm{Cl}} / \mathrm{X}_{\mathrm{Cl}}\right)$ was possible by comparing Samples $\mathrm{V}-3$ and L-3, representing vapor leaving and liquid entering Stripping Section 2 (Figure 1). Values of greater than 1 were indicated for both Runs 11B and 12B. Placement of the reflux divider at this point or even lower in the column was supported by the chloride data of Run 12B. No work was done in withdrawing a sidestream from the divider in the preliminary testing program and might not be justified in view of the high chloride removal via the distillate. The chloride data collected are admittedly erratic, and Sample V-6, showing consistently lower values than the distillate, is highly suspect. Nevertheless, a meaningful trend of chloride distribution in the column was established. On the other hand, chloride levels of 20 to $30 \mu \mathrm{g} / \mathrm{g}$ in the product were higher than desired. It is known that levels of 5 to $10 \mu \mathrm{g} / \mathrm{g}$ chloride will not seriously corrode uranium process stainless steel evaporators. Still acid product containing 5 to $10 \mu \mathrm{g} / \mathrm{g} \mathrm{Cl}-$ would, therefore, be desirable although the incremental corrosion by $30 \mu \mathrm{g} / \mathrm{g} \mathrm{Cl}^{-}$has not been, but should be, established along with the chloride analytical accuracy. Still product chloride content should be verified in upcoming sustained operations in view of the 1.5 to $11 \mu \mathrm{g} / \mathrm{g}$ chloride levels that were achieved in a bubble-cap-type nitric acid distillation system. (2)

Fluoride Distribution and Control - The same operational tests just described for chloride distribution also gave fluoride distribution data. In contrast to the chlorides, fluorides were concentrated in the column stripping section and were not volatilized from the reboiler, severely contaminating the product to unacceptably high levels of $\sim 200 \mathrm{ppm}$. Corrosion of stainless steel by boiling concentrated nitric acid containing $200 \mu \mathrm{g} / \mathrm{g} \mathrm{F}^{-}$is given (2) as 500 mils/year $(1.3 \mathrm{E}-02 \mathrm{~m} / \mathrm{yr})$. Although the pattern of fluoride levels in the-column is again somewhat erratic, buildup of $360 \mu \mathrm{g} / \mathrm{g} \mathrm{F}^{-}$in the vapor and $600 \mu \mathrm{g} / \mathrm{g} \mathrm{F}^{-}$in the liquid (Samples V-4 and L-3 in Run 12B, Table 1) were detected. The buildup of fluorides in the column was much higher in the vapor feed operations (Run 12) than in the liquid feed (Run 11). Abuut $13 \%$ of the bulk fluoride input was removed in the distillate at concentrations of 1.5 to $13 \mu \mathrm{g} / \mathrm{g} \mathrm{F}$ (Runs $11 \mathrm{~B}$ and $12 \mathrm{~B}$ ).

A final test (-Run 14) was made using the chemical fluoride trap to verify its effectiveness in limiting fluoride input to the column and to assess consequent still product quality.

Results of the five-hour run using nitric acid spiked with HF to $35 \mu \mathrm{g} / \mathrm{g} \mathrm{F}^{-}$showed dramatic improvement over Run 12, and the product contained an acceptable $6.6 \mu \mathrm{g} / \mathrm{g} \mathrm{F}^{-}$. Although the vaporizer output was not sampled, the column vapor sample (Sample V-4) indicated that the vapor feed to the columin was less than $1.7 \mu \mathrm{g} / \mathrm{g} \mathrm{F}^{-}$. Sample $V-4$ represents a mixture of reed vapor and vapor rising from the stripping section. Liquid in the stripping section (Sample L-3) showed a fluoride buildup of $18 \mu \mathrm{g} / \mathrm{g}$, or $\sim 3$ times the product concentration of Run 12. The test showed that column fluoride buildup occurred, but that its magnitude was drastically reduced by the chemical trap's removal of incoming feed fluoride. 


\section{Phase II Operation - Condensate Waste Feed}

Condensate wastes were continuously processed for 15 days in the pilot plant to provide data for evaluating distillation performance, separation of feed impurities, and the material's corrosion resistance. The acid content of the feed and still output streams was routinely analyzed to indicate the effect of feed acid variations on the product and distillate (Figure 2): Product contamination, fluoride trap effectiveness, and system distribution of uranium, chloride, fluoride, and organic impurities were evaluated from analyses of the system samples (Table 3 ). Corrosion attack on specimens suspended in the reboiler was measured (Table 4) and a plastic-lined column section tested.

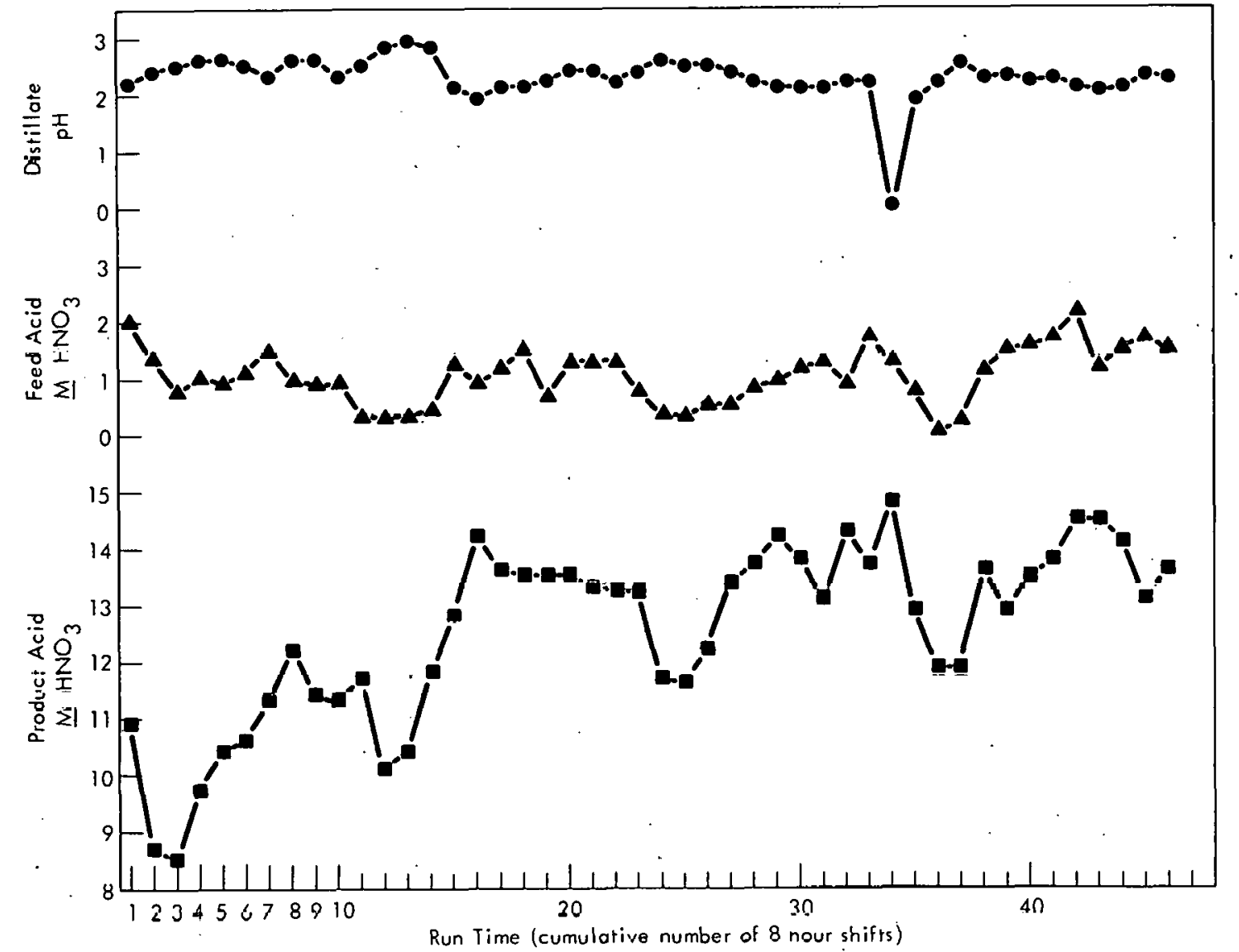

Figure 2. CONTINUOUS PILOT PLANT PROCESSING OF CONDENSATE WASTE. (Acid Content of Feed, Product, and Distillate Streams)

In addition to the processing campaign, laboratory and pilot plant tests were made in attempts to curtail the organic reactions which released nitrogen oxide gas during an abbreviated startup of a second processing campaign. Extraction shakeouts and activated carbon adsorption tests were made to remove organics from the condensate wastes. $A$ column extraction system was added and pilot plant runs were made (Table 5 ) to test the effectiveness of an organic removal system and also to eliminate other potential causes of the observed reaction phenomena. Results of these tests and the processing campaign are summarized in the following sections pertinent to process design of a production-scale system. 
Table 3

STREAM IMPURITIES IN CONTINUOUS PILOT PLANT PROCESSING OF CONDENSATE WASTE

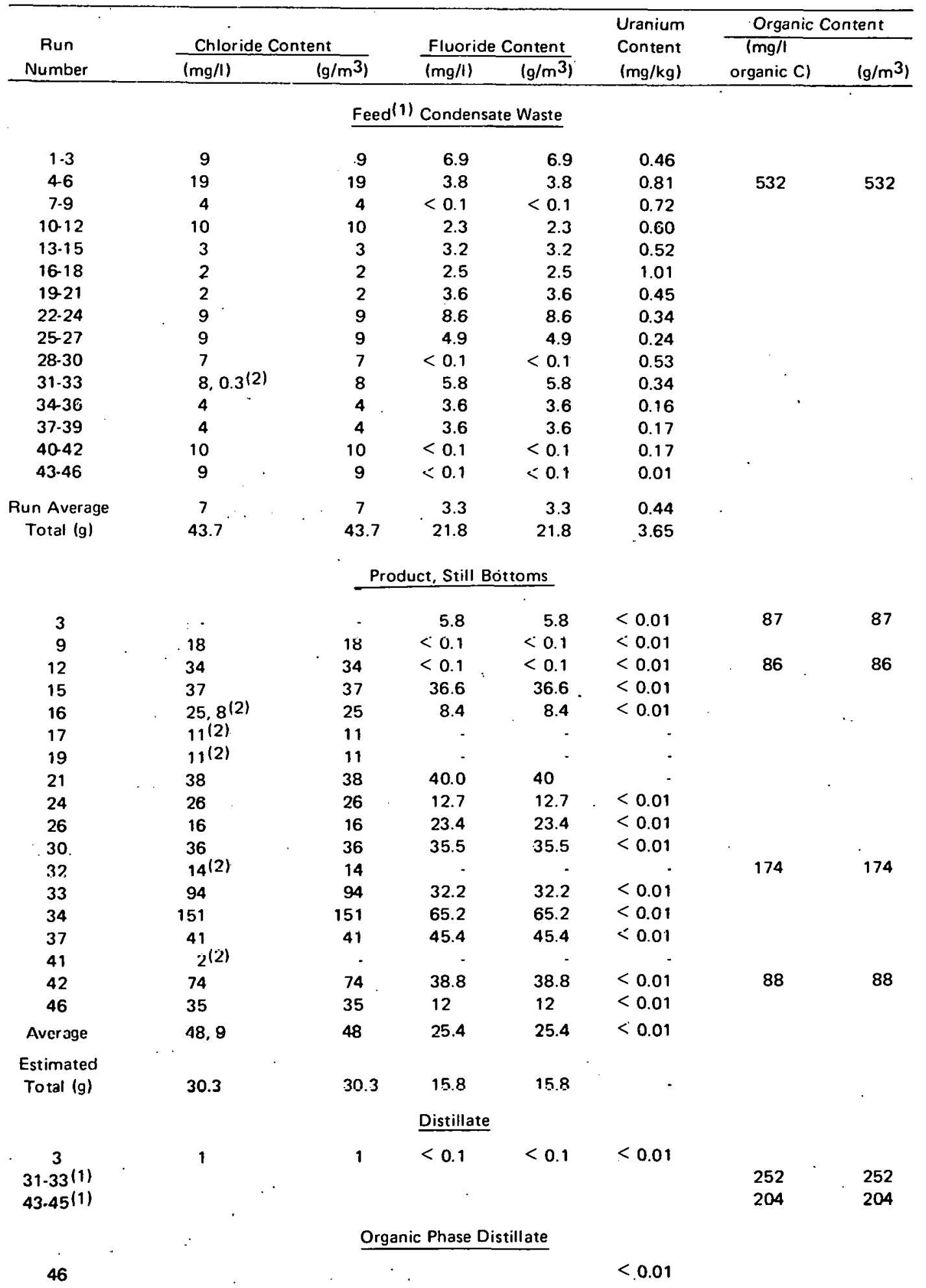

(1) Analyses on composite of three, once-per-shift samples.

(2) Recheck results using an improved analytical method. 
Table 3 (Continued)

\begin{tabular}{|c|c|c|c|c|c|c|c|}
\hline \multirow{2}{*}{$\begin{array}{c}\text { Run } \\
\text { Number }\end{array}$} & \multicolumn{2}{|c|}{ Chloride Content } & \multicolumn{2}{|c|}{ Fluoride Content } & \multirow{2}{*}{$\begin{array}{l}\text { Uranium } \\
\text { Content } \\
\text { (mg/kg) }\end{array}$} & \multicolumn{2}{|c|}{ Organic Content } \\
\hline & $\frac{\text { Chlor }}{\text { (mg/l) }}$ & $\frac{\operatorname{tent}}{\left(\mathrm{g} / \mathrm{m}^{3}\right)}$ & $(\mathrm{mg} / \mathrm{l})$ & $\frac{\text { ontent }}{\left(g / m^{3}\right)}$ & & $\begin{array}{c}(\mathrm{mg} / 1 \\
\text { organic } \mathrm{Cl}\end{array}$ & $\left(g / m^{3}\right)$ \\
\hline \multicolumn{8}{|c|}{ Vaporized Feed (3) } \\
\hline 22 & 11 & 11 & 19 & 19 & & & \\
\hline \multicolumn{8}{|c|}{ Column Liquid (4) } \\
\hline 10 & 19 & 19 & 13.7 & 13.7 & $<0.01$ & & \\
\hline 22 & 9 & 9 & 5.3 & 5.3 & $<0.01$ & & \\
\hline 46 & 25 & 25 & 10.4 & 10.4 & $<0.01$ & & \\
\hline \multicolumn{8}{|c|}{ Vaporizer Nitrate Trap Media(5) } \\
\hline End & 13,445 & 31,445 & 148.9 & 148.9 & 549 & 210 & 210 \\
\hline & $126.3 \mathrm{~g}$ & & $0.6 \mathrm{~g}$ & & $3.07 \mathrm{~g}$ & & . \\
\hline
\end{tabular}

(3) Sampling Point VF in Figure 1.

(4) Sampling Point L-3 in Figure 1.

(5) Aluminum/calcium nitrate solution (fluoride trap) drained from vaporizer at the end of the run.

l'ahle 4

FIELD CORROSION TEST RESULTS ON SELECTED STILL MATERIALS

\begin{tabular}{|c|c|c|c|}
\hline Material Specimen (1) & $\begin{array}{l}\text { Weight Change }(2) \\
\text { (wt \%) }\end{array}$ & $\begin{array}{l}\text { Corrosion Rate } \\
\left(\mathrm{mg} / \mathrm{cm}^{2} \cdot \mathrm{hr}\right)\end{array}$ & Remarks \\
\hline Stainless Steel, 304L & -1.5 & 0.0270 & Uniform at tack. \\
\hline Ironium Aiioy (Ti & $-\mathbf{0 3}$ & 0.15 & Maitifal ulisuilablu. \\
\hline Tantalum & +0.05 & - & $\begin{array}{l}\text { No visible attack, excellent corro- } \\
\text { sion resistance. }\end{array}$ \\
\hline Pyrex Glass & +0.06 & - & $\begin{array}{l}\text { Frosted appearance from fluoride } \\
\text { attack. }\end{array}$ \\
\hline Plastic, "Chemton" Teflon FEP & +0.07 & $\cdot$ & $\begin{array}{l}\text { No visible deterioration of its } \\
\text { physical properties. }\end{array}$ \\
\hline Plastic. "Krnar" & +2.4 & $\cdot$ & $\begin{array}{l}\text { No visible deterioration of its } \\
\text { physical properties. }\end{array}$ \\
\hline Titanium (12-hr exposure only) & -0.2 & 0.0128 & $\begin{array}{l}\text { Surface discolored; thin adherent } \\
\text { coating. }\end{array}$ \\
\hline
\end{tabular}

(1) Pilot-plant reboiler exposure for 361 hours at 230 to $260^{\circ} \mathrm{F}$ in 8 to $15 \underline{\mathrm{M} \mathrm{HNO}} 3$ containing 37 and 25 ppm average of $\mathrm{Cl}^{-}$and $\mathrm{F}^{-}$, respectively.

(2) "“+" represents weight gain: "." represents weight loss.

Feed Source and Operating Conditions - Condensate wastes were processed at operating conditions previously established for $10 \mathrm{wt} \%$, or $1.7-\mathrm{molar}$, acid feed. The operating conditions were: vapor feed to the column at a $23 \mathrm{l} / \mathrm{hr}(6.39 \mathrm{E}-06 \mathrm{~m} 3 / \mathrm{s})$ liquid input to the vaporizer, a 0.33 distillate/reflux ratio, and a 35-psig (2.41 E+05 $\mathrm{Pa}$ ) steam input to the reboilers. The reflux ratio was decreased to 0.17 early in the run to compensate for the dilute acid content of the condensate wastes. Piping and appropriate valving were installed 
Table 5

PILOT PLANT STUDY OF ORGAIVIC REACTIONS

(Summary of Pilot Plant Test Run Data)

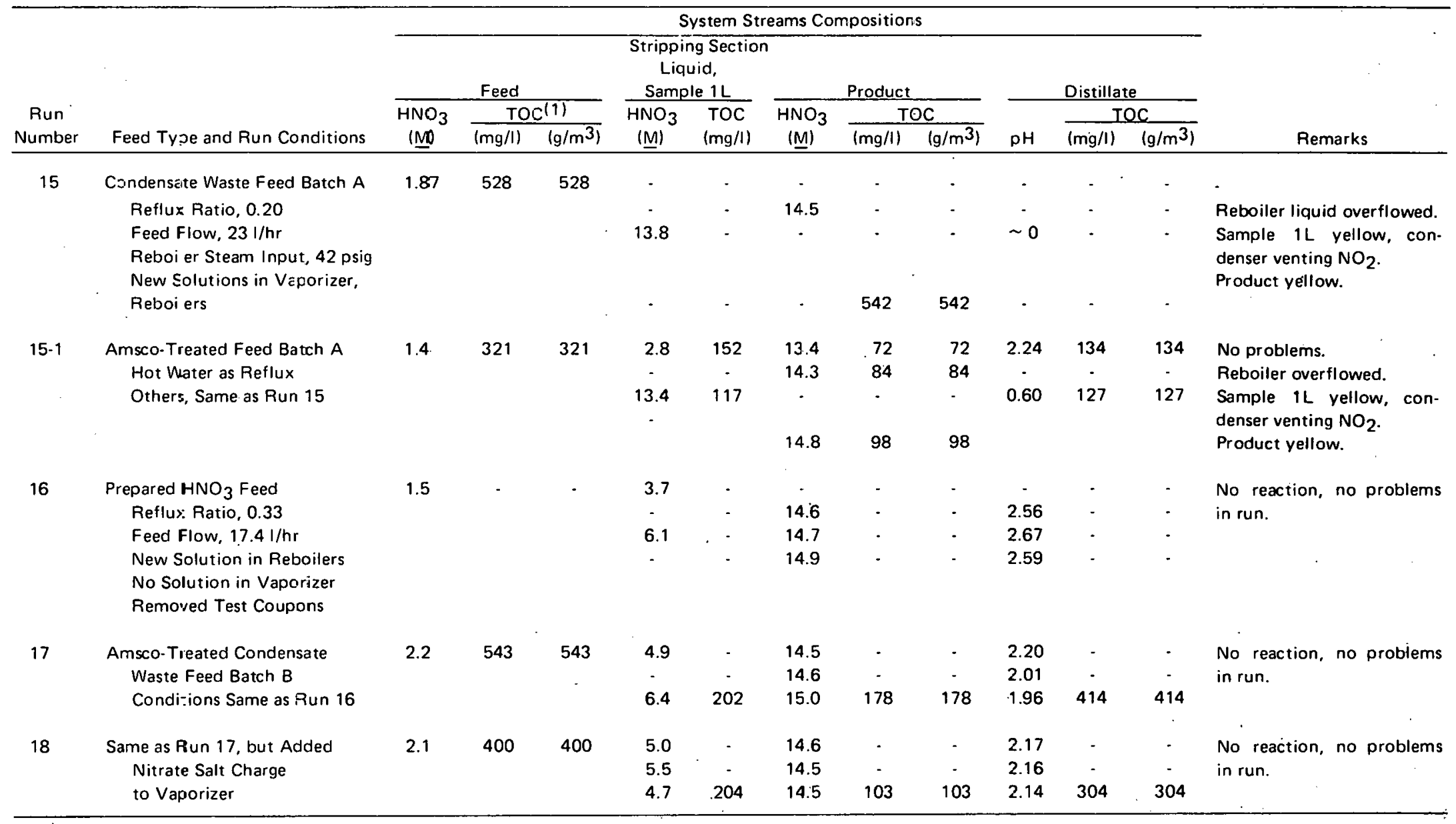

(1) TOC - total organic carbon. 
to receive $\sim 30$ vol \% of each 14-gallon (5.299 E-02 $\mathrm{m}^{3}$ ) condensate batch which was received from the "intermediate" evaporators. These evaporators concentrate the following uranyl nitrate solutions: oxide dissolver product, primary extraction product, denitrator scrubber solution, and "secondary" evaporator condensate. The last three can contain entrained or dissolved dibutyl carbitol (DBC), tributyl phosphate (TBP), kerosene, or degradation products of these compounds. Entrained organics, which do exist as a separate phase, were prevented from entering the still by maintaining a nearly fult level in the 35-gallon (1.325 E-01 $\mathrm{m}^{3}$ )-capacity feed drum. The "intermediate" condensate line also carries condensate from processing dilute 10.2 molar nitrate) Savannah River source solutions. Alterations to the system were made to receive the second major source of condensate waste (the "general salvage" evaporator) which concentrates a variety of dilute nitrate solutions. However, none of this condensate was used in the pilot plant work since the same process line was in sustained use to discard other nonnitrate waste solutions. The pilot plant processed 8280 liters $\left(8.28 \mathrm{~m}^{3}\right)$ of what might be termed typical "intermediate" and Savannah River condensates in the 15-day campaign. The cited volume also includes additions to the feed drum of mixed product and distillate from the still during low uranium processing periods when condensate flows from the plant were inadequate. This procedure was necessary to some degree for the latter one third of the operating period. Before startup, the vaporizer was charged with the fluoride trap media, $4.288 \mathrm{~kg}$ of solution containing $2.273 \mathrm{~kg}$ of calcium nitrate tetrahydrate and $1.020 \mathrm{~kg}$ of aluminum nitrate nonahydrate. The reboilers were charged with 20 liters $\left(2 \mathrm{E}-02 \mathrm{~m}^{3}\right)$ of $64 \mathrm{wt} \% \mathrm{HNO}_{3}$. During operation, the feed drum, product, and distillate streams were sampled once per each eight-hour shift. Temperature and pressure readings were taken twice per each eight-hour shift.

Feed Acid Content and Effect on Still Performance - The acid content of the condensate waste varied; and, at the fixed operating conditions, produced a variable-strength acid product and distillate whose $\mathrm{pH}$. fluctuated generally withın an acceptable range. I he direct relationship of product strength and distillate acidity to feed concentration is evident in a plot of sample analyses (Figure 2). Product and distillate values represent instantaneous stream outputs, while the feed values were determined by sampling the feed drum solution inventory at that time. This difference plus the high reboiler holdup time $(\sim 7 \mathrm{hr})$ accounts for the product lag time in the feed and product values in Figure 2.

The condensate waste feed was more dilute than the anticipated design value of $10 \mathrm{wt} \%$, or 1.1-molar $\mathrm{HNO}_{3}$. The feed ranged from 0.08 to 2.2 molar, and averaged (total moles $\mathrm{HNO}_{3}$ divided by total volume) 1.01 molar acid. (All acid results are by sodium hydroxide titration.)

Reasons for the low acid condensate are currently due to reduced primary extraction operations in the plant, which normally supplies the bulk of the feed to the "intermediate" evaporators, and a recent stabilization of the primary backwash at $7.5 \mathrm{wt} \%\left(1.25 \mathrm{M} \mathrm{HNO}_{3}\right)$. At reduced operations, evaporation of dilute Savannah River solutions, during Shifts 1 to 14 and 23 to 26, in Figure 2, further diluted the condensate acid. These factors should be considered in selecting the feed-acid value for design of the large-scale still. Feed-acid values for Shifts 32 through 46 were influenced higher than normal by the addition of 1.7 molar $\mathrm{HNO}_{3}$ to the feed drum and does not account for the low $(0.08 \mathrm{M})$ acid value obtained on Shift 36. 
The product concentration followed the feed variation, which ranged from 8.5 to 14.8 molar, and averaged 12.5 molar acid. The product concentration was improved by progressively reducing the distillate reflux ratio from 0.33 to 0.17 , which is 1.2 times the 0.14 minimum reflux ratio calculated for the more dilute $(1 \mathrm{M})$ acid feed. The decreased reflux, in effect, removed some of the reboiler heat load. The reflux change was made during Shifts 7 through 10, and the product since Shift 10 ranged from 10.1 to 14.8 and averaged 13.4 molar $\mathrm{HNO}_{3}$. The uranium purification plant has used commercial $\mathrm{HNO}_{3}$ of different strengths in the 13 to 14 -molar concentration range. The specific concentration is less important than its consistency for conformance to continous flow usage. A large feed reservoir in the production-scale still should dampen the feed land therefore the product)/acid variations evidenced in the pilot plant tests. Longer-term variation of the mixed waste streams will probably require automated control to achieve a consistent product concentration. Control of reboiler steam input by measurement of reboiler product concentration, boiling point, or density is preferred to control of the feed flow in a system designed to operate at or near the flooding point.

The acidity of the distillate varied directly with the feed within a pH range of 1.9 to 2.9 , and averaged 2.3. These values are equivalent, respectively, to 794,79 , and $316 \mu \mathrm{g} / \mathrm{g}^{\mathrm{HNO}} \mathrm{N}_{3}$, which are not considered to be significant. The major portion of the run was made at the reduced 0.17 reflux ratio, but there was no appreciable sacrifice in distillate acidity in comparing distillate $\mathrm{pH}$ values before and after Shift 10 , corresponding to equal feed concentrations. The distillate $\mathrm{pH}$ at reduced reflux conditions also averaged 2.3. The abnormally low (zero $\mathrm{pH}$ ) value observed during Shift 34 was initially thought to be due to an inadvertent slugging of the feed drum with concentrated acid. At the same time, $\mathrm{NO}_{2}$ was observed to vent from the condenser. It was later found, as explained in a following section, that these effects are indicative of an organic reaction. There was only one such incident in the pilot plant campaign. The distillate volume (92.1 vol \% of feed input) contained only 0.46 wt \% of the total nitrate input, which illustrates the system's high (99.5\%) efficiency in recovering $\mathrm{HNO}_{3}$ from condensate waste. The overall distillate flow rate was $21.2 \mathrm{l} / \mathrm{hr}\left(5.89 \mathrm{E}-06 \mathrm{~m}^{3} / \mathrm{s}\right)$, although it varied inversely with the feed concentration.

Impurities Distribution - System sample analyses were made in the pilot plant processing of cundensate waste to determine the feed input, distribution, and effect on product quality of impurities critical to stıll design and product reuse. The analytical data are summarized in Table 3 and their importance is discussed in the following four subsections dealing with each of the specific impurities.

Uranium - Excellent uranium separation was achieved within the pilot plant feed vaporizer. Condensate wastes entered the vaporizer at 0.01 to $1.01 \mu \mathrm{g} / \mathrm{g}$ and averaged $0.44 \mu \mathrm{g} / \mathrm{g}$ (see Table 3 ). The product consistently analyzed below the detection limit of $0.01 \mu \mathrm{g} / \mathrm{g}$ uranium as did one distillate and three column liquid samples. Uranium was retained by the fluoride trap solution in the vaporizer, as verified by the $549 \mu \mathrm{g} / \mathrm{g}$ uranium analyzed in the trap media at the termination of the run. This amount accounted for $3.07 \mathrm{~g}$, or $84 \mathrm{wt} \%$, of the $3.65 \mathrm{~g}$ uranium input estimated from the once-per-shift sampling of the feed drum. These results show that proper vaporizer design and operation can eliminate consideration of nuclear safe geometry for the distillation tower and still output storage tanks. 
Potential buildup of trace amounts of radionuclides was also studied. Feed, product, and distillate samples, taken during Shifts $22-24$, were analyzed by gamma spectrometry. There was no detectable amount of ruthenium-106, the volatile and most likely constituent, nor of any other radionuclides in the three samples. However, a slight amount of Ru-106 was trapped in the fluoride trap solution which analyzed $911 \mathrm{dis} / \mathrm{min} / \mathrm{ml}\left(1.521 \mathrm{E}+07 \mathrm{dis} / \mathrm{s} / \mathrm{m}^{3}\right)$ of Ru-106 activity.

Chtorides - An evaluation of pilot plant sample analyses (Table 3) created ambiguous conditions of chloride transfer in the system and provided no conclusive level of chloride contamination in the acid product stream. Evaluation was difficult because of the dependence on the high analytical accuracy in the $<100 \mu \mathrm{g} / \mathrm{g} \mathrm{Cl}$ - detection range. Chloride analyses were largely restricted to the feed and product in the course of pilot plant operations while holding the distillate and other samples for future evaluation, if required.

Initial results indicated that condensate waste chloride input was concentrated in the product stream (see Table 3). The feed contained 2 to $19 \mu \mathrm{g} / \mathrm{g} \mathrm{Cl}$ - (averaged $7 \mu \mathrm{g} / \mathrm{g}$ $\left.\mathrm{Cl}^{-}\right)$and introduced an estimated 43.7 grams of chloride to the system. The product (18 of 46 shift samples) analyzed 16 to $151 \mu \mathrm{g} / \mathrm{g} \mathrm{Cl}^{-}$(averaging $48 \mu \mathrm{g} / \mathrm{g} \mathrm{Cl}^{-}$) and carried an estimated $30.3 \mathrm{~g}$, or $69 \mathrm{wt} \%$, of the input $\mathrm{Cl}^{-}$from the system. The average feed and product values are in agreement with the 8.2-to-1 weight concentration factor of the pilot plant run. That is, a $7 \mu \mathrm{g} / \mathrm{g} \mathrm{Cl}^{-}$feed would provide a $57 \mu \mathrm{g} / \mathrm{g} \mathrm{Cl}^{-}$product if there was no chloride loss to the distillate. The one distillate sample taken was very low $\left(1 \mu \mathrm{g} / \mathrm{g} \mathrm{Cl}^{-}\right)$. Furthermore, the stripping section liquid samples were low (9 to $25 \mu \mathrm{g} / \mathrm{g} \mathrm{Cl}^{-}$) and did not reflect the usual high chloride buildup at this point in the system. These findings inferred a transfer and concentration of feed chlorides into the product stream, which contradicted Phase 1 work showing $70 \mathrm{wt} \%$ chloride removal in the distillate and a chloride buildup in the column six times that of the product.

The high product chloride values violated known chloride volatility data and inverse relationship of $\mathrm{Cl}^{-}$with $\mathrm{HNO}_{3}$ concentration in an $\mathrm{HCl}-\mathrm{HNO}_{3}$ chemical system. There was no apparent product $\mathrm{Cl}^{-}$correlation in processing condensate waste with an $\mathrm{HNO}_{3}$ content. In fact, the highest $\mathrm{Cl}^{-}$result $(151 \mu \mathrm{g} / \mathrm{g})$ was detected in the highest, near-azeotropic, 14.8-molar $\mathrm{HNO}_{3}$ product achieved (see Shift 34, Table 3, and Figure 2). Contributing to these anomalies was an analysis of the vaporizer's fluoride trap media at the end of the run which showed chloride buildup to 31445 $\mu \mathrm{g} / \mathrm{g}$ which is equivalent to $126.3 \mathrm{~g} \mathrm{Cl}^{-}$, or three times the calculated feed input.

Significantly lower chloride levels were found in both product and feed by a reportedly improved analytical technique. Five product samples ranged from 2 to 14 $\mu \mathrm{g} / \mathrm{g} \mathrm{Cl}^{-}$and averaged $9 \mu \mathrm{g} / \mathrm{g} \mathrm{Cl}^{-}$, while the only feed sample ran $0.3 \mu \mathrm{g} / \mathrm{g} \mathrm{Cl}^{-}$. One product and the feed sample were recheck analyses (see Table 1). Although the resample results indicated that acid of acceptable purity was produced, they also implied that the original analyses were biased high, presumably including the distillate and stripper section liquid samples; and, therefore, did not clarify the chloride distribution ambiguity. In view of further problems with fluorides, chlorides, and organics, it was tentatively concluded that impurities in condensate 
waste required further laboratory work to define their form and reaction in a distillation system.

Fluorides-Chemical malfunction of the vaporizer's fluoride trap media allowed fluoride to enter the distillation tower where it concentrated in the product. The condensate waste contained $<0.1$ to $8.6 \mu \mathrm{g} / \mathrm{g} \mathrm{F}^{-}$, at an average of $3.3 \mu \mathrm{g} / \mathrm{g} \mathrm{F}^{-}$, and fed an estimated $21.8 \mathrm{~g} \mathrm{~F}^{-}$to the system. Three product samples in the first 12 shifts of operation contained 5.8 and $<0.1 \mu \mathrm{g} / \mathrm{g} \mathrm{F}$, after which fluoride fluctuated in the 8.4 to $65.2 \mu \mathrm{g} / \mathrm{g}$ range. The product averaged $25.4 \mu \mathrm{g} / \mathrm{g} \mathrm{F}^{-}$overall, totaling an estimated $15.8 \mathrm{~g} \mathrm{~F}^{-}$, or $72 \mathrm{wt} \%$ of the feed input. The possibility that the trap was fluoride saturated in the first 12 shifts was not substantiated by analysis of the trap media at the end of the run, which showed only $148.9 \mu \mathrm{g} / \mathrm{g}$ and $0.6 \mathrm{~g} \mathrm{~F}^{-}$, or about 3 wt $\%$ of the feed input. Saturation values to $20000 \mu \mathrm{g} / \mathrm{g}$ had been determined $(5)$ in developing the fluoride trap concept. The relative magnitude of fluoride in the feed, product, distillate, and other points in the system (Table 3) were comparable to those found in the Phase I work without the trap. Apparent failure of the trap while processing condensate waste is possibly due to a reduced capacity or changed equilibrium with the more dilute $\mathrm{HNO}_{3}$ feed. More likely, it is a function of the fluoride specie or interfering impurities in condensate waste that were not present in the synthetic feed solutions.

Organics and Organic Reactions - The condensate waste contained dissolved organics which distilled upwards and were partially removed, both as separate and soluble phases, with the distillate. The organic presence caused no violent acid reactions in the pilot plant processing campaign, although evidence of a reaction was later observed. Samples were analyzed for total organic carbon (TOC) (Table 3) to determine the magnitude of organics in the system. A feed sample contained 532 $\mathrm{mg} / /\left(5.32 \mathrm{E}-01 \mathrm{~kg} / \mathrm{m}^{3}\right) \mathrm{TOC}$, and infrared (IR) analysis identified dibutyl carbitol (DBC). Two distillate samples contained 204 and $252 \mathrm{mg} / \mathrm{l}(2.04$ and $2.52 \mathrm{E}-01$ $\mathrm{kg} / \mathrm{m}^{3}$ ) TOC. In addition, $365 \mathrm{ml}\left(3.65 \mathrm{E}-04 \mathrm{~m}^{3}\right)$ of organics trapped in the distillate cooler were identified as a mixture of DBC and tributyl phosphate (TBP), the two uranium extractants in use. Significantly, no organic nitrates were detected in the collected distillate organic phase. That is, DBC and TBP were vaporized and flowed through the system as such, without decomposition. Three product samples analyzed 86 to $88 \mathrm{mg} / 1\left(8.8 \mathrm{E}-02 \mathrm{~kg} / \mathrm{m}^{3}\right)$ TOC, while a fourth sample taken near the time of a suspected organic reaction contained $174 \mathrm{mg} / \mathrm{l}\left(1.74 \mathrm{E}-01 \mathrm{~kg} / \mathrm{m}^{3}\right)$ TOC. Although DBC and TBP have high boiling points [ 254 and $289^{\circ} \mathrm{C} / 527$ and $562 \mathrm{~K})$ ], there was no organic buildup in the vaporizer. The nitrate media analyzed $210 \mathrm{mg} / \mathrm{l}\left(2.10 \mathrm{E}-01 \mathrm{~kg} / \mathrm{m}^{3}\right)$ TOC, which reflected the approximate $1: 1$ dilution of media with feed as vaporizer holdup. It was estimated from these few analyses that, at least, $50 \mathrm{wt} \%$ of the TOC input was removed by the distillate and about 3 wt \% of it was retained in the product in some unidentified form.

Evidence of an organic acid reaction was first documented, and then repeated, only while using a particular batch of condensate waste (termed Batch $A$ ) that had been collected for pilot plant startup of a second processing campaign. The system had been operating for four hours at conditions identical to the first campaign except for two process changes. The reboiler steam input was increased to $42 \mathrm{psig} 12.9 \mathrm{E}+05$ 
$\mathrm{Pa}$ ) in order to lower the product chloride content, and the feed was spiked with 20 ppm $(20 \mu \mathrm{g} / \mathrm{g})$ aluminum to promote ${ }^{(5)}$ trapping of the fluoride in the vaporizer. The organic reaction was not catastrophic and can be characterized by the following series of events: Enough pressure was created (evidently by gas formation in the reboiler section) to drive about 6 inches $(1.524 \mathrm{E}-01 \mathrm{~m})$ of reboiler liquid level out through the product line (see Figure 1). Within 30 minutes (1.8 E+03 s), the column stripper section liquid which collects in the reflux divider (L-3 in Figure 1) attained a dark yellow color, and gas bubbles were generated and escaped from the liquid pool. At the same time, the distillate flow was highly acidic, and a reddish brown vapor (typical of $\mathrm{NO}_{2}$ ) emerged from the condenser vent. Yet, the gas or vapor phase in the entire column system, including the condenser, was colorless until it contacted air, which suggests nitric oxide (NO). The reboiler liquid later turned yellow from the downcoming stripper section reflux which entered the center leg of the reboiler section and continued to generate gas bubbles. On shutdown, copious $\mathrm{NO}_{2}$ fumes formed in the reboiler and lower column, probably from air backflow through the condenser as the column system cooled. The reaction then subsided without incident and the $\mathrm{NO}_{2}$ was absorbed by the acid. Analyses of a subsequent reboiler acid sample showed $542 \mathrm{mg} / /\left(5.42 \mathrm{E}-01 \mathrm{~kg} / \mathrm{m}^{3}\right)$ TOC as a mixture of organic nitrates. There was no DBC or TBP detected. The particular condensate waste (Batch A) contained $562 \mathrm{mg} / \mathrm{l}\left(5.62 \mathrm{E}-01 \mathrm{~kg} / \mathrm{m}^{3}\right.$ ) TOC.

Laboratory Tests to Remove Feed Organics - Laboratory experiments were made using Feed Batch $A$ to explore methods for removing the feed organics. Extraction shakeouts were made with Amsco $125-82$, (c) a commercial kerosene product in which both DBC and TBP are soluble. After contacting an equal volume $\left[100 \mathrm{ml}\left(1.0 \mathrm{E}-04 \mathrm{~m}^{3}\right)\right]$ of Amsco and feed, the feed TOC had been reduced from 562 to $320 \mathrm{mg} / \mathrm{l}\left(5.62\right.$ to $\left.3.20 \mathrm{E}-01 \mathrm{~kg} / \mathrm{m}^{3}\right)$. The 100 milliliters of Amsco were then contacted with three more aliquots of feed [totaling $1850 \mathrm{ml}$ $\left.\left(1.850 \mathrm{E}-03 \mathrm{~m}^{3}\right)\right]$ to produce TOC values of 334,376 , and $390 \mathrm{mg} / \mathrm{l}(3.34,3.76$, and 3.90 E- $01 \mathrm{~kg} / \mathrm{m}^{3}$ ) in the aqueous phases. These results indicated that the Amsco was not saturated with the extracted organic. To test the solubility of Amsco in $\mathrm{HNO}_{3}$, equal volumes of 2-molar $\mathrm{HNO}_{3}$ and $A$ msco were contacted. The $\mathrm{HNO}_{3}$ analyzed $49 \mathrm{mg} / \mathrm{l}(4.9$ $E-02 \mathrm{~kg} / \mathrm{m}^{3}$ ) TOC before and after contact. It, therefore, appeared that Amsco was not removing all of the organics from Feed Batch $A$. A shakeout using perchloroethylene was no better in that the TOC content was reduced to $326 \mathrm{mg} /\left(3.26 \mathrm{E}-01 \mathrm{~kg} / \mathrm{m}^{3}\right)$.

The Amsco-treated feed was submitted for analytical detection of the organics remaining in solution. The Plant Laboratory extracted aliquots of the feed with petroleum ether, Freon, cyclohexane, methyl chloroform, and tetrachlorethene. The first three extractants reduced the TOC in the aqueous phase from 321 to 236,238 , and $268 \mathrm{mg} / \mathrm{l}(3.21$ to $2.36,2.38$, and $2.68 \mathrm{E}-01 \mathrm{~kg} / \mathrm{m}^{3}$ ), respectively. IR analysis of the extract showed DBC, oxidized organics, organic nitrates, an organic acid, and a plasticizer.

Two other methods were briefly tested for removing the residual organics from the Amsco-treated Feed Batch A. The solution was allowed to flow at $0.81 \mathrm{gal} / \mathrm{min}-\mathrm{ft}^{2}(5.50$

(c) Product of the American Mineral Spirits Company. 
E-04 $\left.\mathrm{m}^{3} \mathrm{~s}-\mathrm{m}^{2}\right)$ through a small $\left[67 \mathrm{ml}\left(6.70 \mathrm{E}-05 \mathrm{~m}^{3}\right)\right]$ column bed of Columbia-Grade ACC activated carbon. (d) The first five column volumes analyzed 81 to $96 \mathrm{mg} / \mathrm{l}$ ( 8.1 to 9.6 E-02 kg/m 3 ) TOC and increased to $288 \mathrm{mg} / \mathrm{l}\left(2.88 \mathrm{E}-01 \mathrm{~kg} / \mathrm{m}^{3}\right)$, or close to the $336 \mathrm{mg} / \mathrm{l}$ (3.36 E- $01 \mathrm{~kg} / \mathrm{m}^{3}$ ) starting value after a throughput of 16 column volumes. A column bed, 26 in $(6.604 \mathrm{E}-01 \mathrm{~m})$ in diameter by $15.6 \mathrm{ft}(4.755 \mathrm{~m})$ high, was calculated to be necessary to treat $3 \mathrm{gal} / \mathrm{min}(1.89 \mathrm{E}-04 \mathrm{~m} / \mathrm{s})$ of condensate waste at the arbitrary flow rate used in the test and assuming a breakthrough point of 10 column volumes and bed regeneration once every 24 hours $\left(8.64 \times 10^{4} \mathrm{~s}\right)$. A static bed test was also made where the carbon was equilibrated with 2-molar $\mathrm{HNO}_{3}$ to remove a constituent which had reacted and caused an outgas disruption of the column bed in the first test. The $800 \mathrm{ml}\left(8.00 \mathrm{E}-04 \mathrm{~m}^{3}\right)$ of preconditioned carbon was covered with $250 \mathrm{ml}\left(2.50 \mathrm{E}-04 \mathrm{~m}^{3}\right)$ of Amsco-treated Feed Batch A solution. After an overnight standing, the feed had been reduced to $33 \mathrm{mg} / \mathrm{l}$ (3.3 $\mathrm{E}-02 \mathrm{~kg} / \mathrm{m}^{3}$ ) TOC. Further work to optimize the process conditions and define a suitable regeneration procedure might offer a more attractive process than was first indicated.

Organic destruction by hydrogen peroxide $\left(\mathrm{H}_{2} \mathrm{O}_{2}\right)$ was also tested with only moderate success. Amsco-treated Feed Batch $\mathrm{A}$ was adjusted to 3.4-molar $\mathrm{H}_{2} \mathrm{O}_{2}$ and heated to boiling for an hour, a procedure previously used on organic-bearing uranium solutions. The feed was reduced from 362 to $128 \mathrm{mg} / \mathrm{l}$ (3.62 to $1.28 \mathrm{E}-01 \mathrm{~kg} / \mathrm{m}^{3}$ ) TOC.

Pilot Plant Tests on Organic Reaction - Short pilot plant runs were made to verify (possibly curtail) the organic reaction and to further test the effectiveness of the Amsco pretreatment of the feed. The operating conditions and results, including those of the attempted startup (termed Run 15) are summarized in Table 5. An Amsco contacting system was installed in the pilot plant to pretreat condensate waste prior to input to the still. The system (Figure 3) was a spray-type column, 6 inches $(1.524 \mathrm{E}-01 \mathrm{~m})$ in diameter by 10 feet $(3.048 \mathrm{~m})$ high, followed by a phase separation column holding polyethylene coalescing elements. A flow rate of $1.3 \mathrm{gal} / \mathrm{min}(8.20 \mathrm{E}-05 \mathrm{~m} 3 / \mathrm{s})$ water into the static Amsco was ascertained to be proper for good phase separation characteristics. This conclusion was verified by TOC analyses of the water input and output as 31 and $21 \mathrm{mg} / \mathrm{l}\left(3.1\right.$ and $\left.2.1 \mathrm{E}-02 \mathrm{~kg} / \mathrm{m}^{3}\right)$, respectively. Feed Batch $A$ was then treated and, in one pass through the column, the TOC dropped from 528 to $321 \mathrm{mg} / \mathrm{l}$ ( 5.28 to $\left.3.21 \mathrm{E}-01 \mathrm{~kg} / \mathrm{m}^{3}\right)$, which duplicated the shakeout results.

Amsco-treated Feed Batch A was processed in the distillation pilot plant (Run 15-1, Table $5)$, but the identical reaction symptoms reappeared, indicating that the Amsco treatment of the feed was ineffective. The pilot plant had been thoroughly washed out prior to Run 15-1 and the vaporizer and reboilers were charged with new nitrate and $\mathrm{HNO}_{3}$ solutions to eliminate the contamination effects from Run 15. In addition, provision was made to substitute hot [ 180 to $200^{\circ} \mathrm{F}(355$ to $366 \mathrm{~K})$ ] water for distillate as the reflux (see Figure 4). Run 15-1 was made with total distillate withdrawal and hot water reflux to eliminate organics reentering the column as condensed distillate reflux. Hopefully, organics fed to the column midpoint as vapor would be totally removed in the distillate. However, this procedure did not prevent an organic reaction in Run 15-1. The product contained 72 to 98 $\mathrm{mg} / \mathrm{l}\left(7.2\right.$ to $\left.9.8 \mathrm{E}-02 \mathrm{~kg} / \mathrm{m}^{3}\right)$ TOC.

(d) Product of the Union Carbide Corporation-Carbon Products Division. 


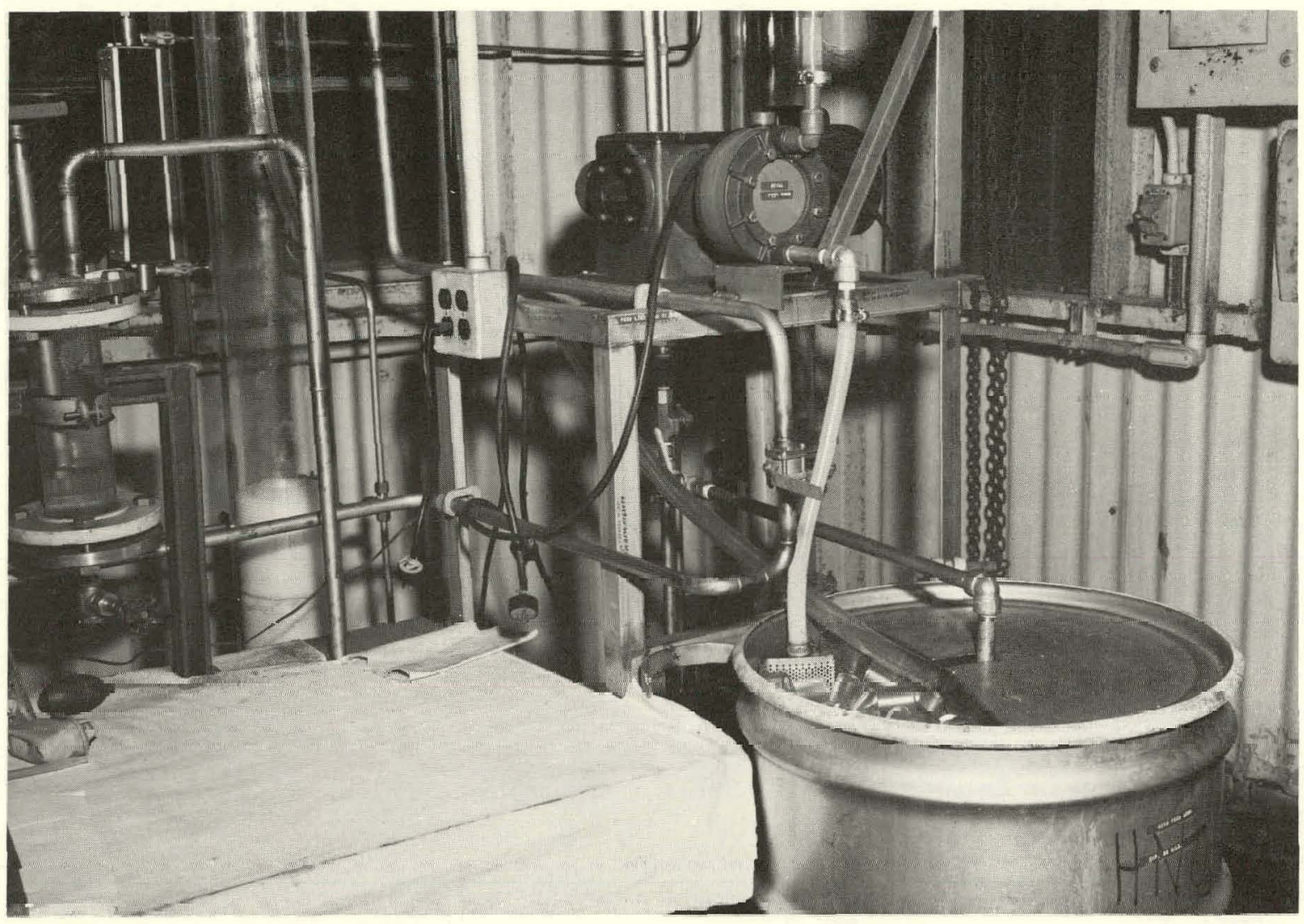

154322

Figure 3. CONDENSATE WASTE RECEVING AREA OF THE PILOT PLANT SYSTEM. (Extraction and Phase Separator Columns Used in Runs 15-1, 17, and 18 are Seen Behind the Glass-Packed, 55-Gallon Feed Drum)

A pilot plant test (Run 16, Table 5) was made to dispel the possibility that the $\mathrm{NO}_{2}$ releasing reaction was caused by concentrated $\mathrm{HNO}_{3}$ decomposition rather than organics. For this test, the pilot plant was again thoroughly cleaned out, new acid charged to the reboilers, the vaporizer nitrate media was omitted, and metal test coupons removed from the reboiler to eliminate all other sources of $\mathrm{NO}_{2}$ generation. There was no reaction, $\mathrm{NO}_{2}$, or yellow solutions formed in converting 1.5-molar $\mathrm{HNO}_{3}$ feed to 14.9-molar acid product. This test also showed that the stripping-section liquid (at Sampling Point 16, Figure 1) was 6-molar $\mathrm{HNO}_{3}$, with 14.7-molar $\mathrm{HNO}_{3}$ conditions in the reboiler. The 13.4 and 13.8-molar $\mathrm{HNO}_{3}$ found in Runs 15 and 15-1 was, therefore, abnormal and was the effect of an organic reaction rather than the cause. The high acid is probably caused by absorption of nitrogen oxides released by an organic reaction in the reboiler or stripping section.

Two more pilot plant tests were made (Runs 17 and 18, Table 5) using a different condensate waste (Feed Batch $B$ ) which produced no reaction. Feed Batch B was treated with Amsco, but the TOC $\left[518 \mathrm{mg} / \mathrm{l}\left(5.18 \mathrm{E}-01 \mathrm{~kg} / \mathrm{m}^{3}\right)\right]$ was unaffected or moderately reduced [543 and $400 \mathrm{mg} / \mathrm{l}\left(5.43\right.$ and $\left.\left.4.00 \mathrm{E}-01 \mathrm{~kg} / \mathrm{m}^{3}\right)\right]$ in Runs 17 and 18 . Nevertheless, the 2-molar $\mathrm{HNO}_{3}$ feed was concentrated to 15.0-molar product acid in Runs 17 and 18 with no sign of a reaction. Distillate TOC of 300 to $400 \mathrm{mg} / \mathrm{l}\left(3\right.$ to $\left.4 \mathrm{E}-01 \mathrm{~kg} / \mathrm{m}^{3}\right)$ was roughly equivalent to $75 \mathrm{wt} \%$ of the TOC input, and the still product contained 103 and $178 \mathrm{mg} / \mathrm{l}\left(1.03\right.$ and $\left.1.78 \mathrm{E}-01 \mathrm{~kg} / \mathrm{m}^{3}\right)$ TOC. The vaporizer charge of nitrate trap media in 


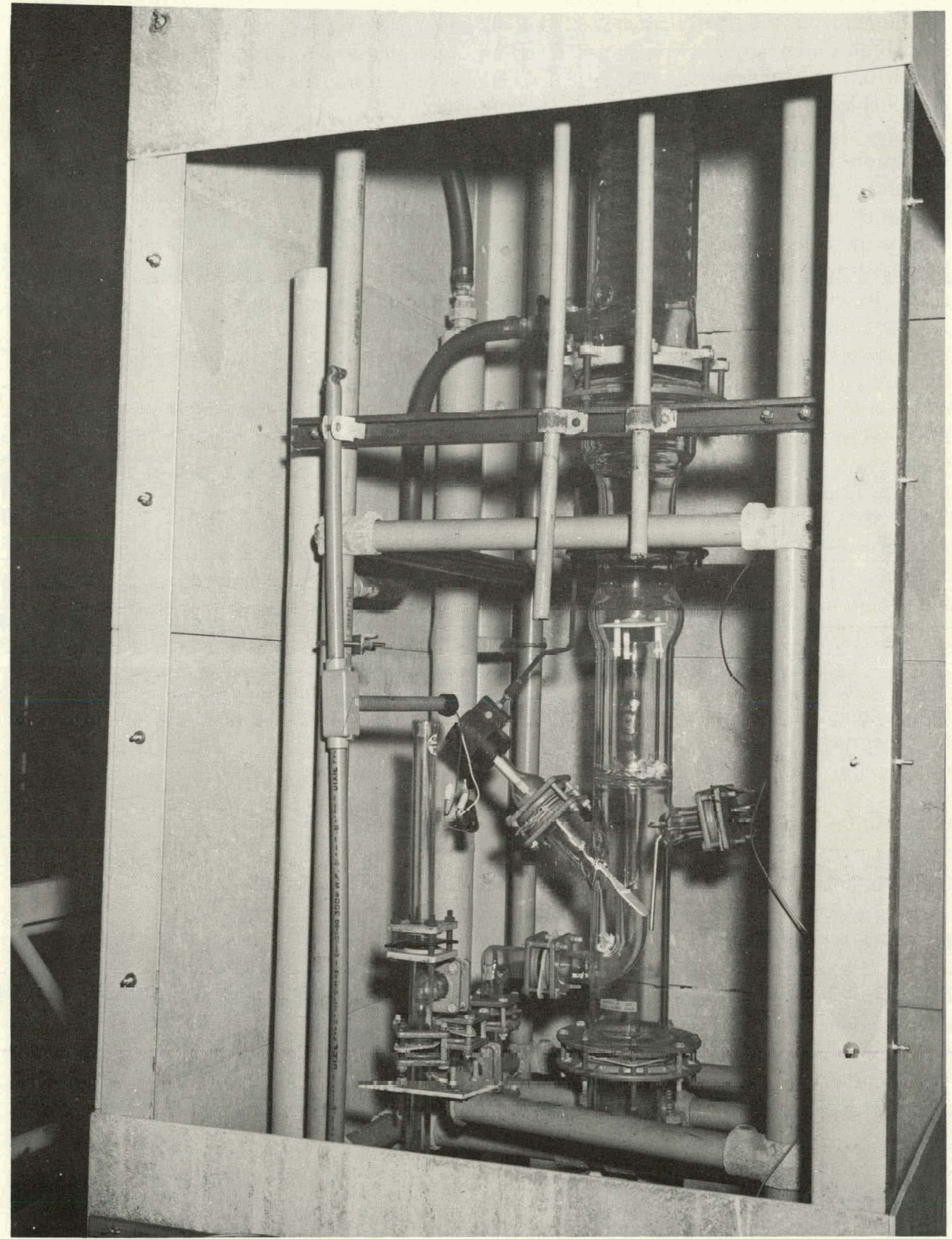

154320

Figure 4. TOP OF DISTILLATION TOWER, CONDENSER, AND REFLUX SPLITTER. (Hot-Water Reflux Line Used in Run 15-1 is Seen Entering at Right. Directly Opposite the Splitter) 
Run 18 did not alter (through possible salt decomposition) the results of Run 17. It was concluded from the pilot plant tests that some condensate waste, represented by Feed Batch $A$, contains a constituent (presumed to be an organic) that is unextractable by Amsco and does react in concentrated $\mathrm{HNO}_{3}$. Further work to define the differences in source and composition of Feed Batches $A$ and $B$ is in progress.

Corrosion Field Tests-Materials of Construction-Specimens of selected materials were suspended in the reboiler during the 15-day processing campaign to evaluate their corrosion resistance for specifying reboiler and column construction materials. The results (Table 4) clearly indicated superiority of tantalum over the other two metals as a reboiler material. Stainless steel (Type 304L) withstood chloride and fluoride attack better than anticipated since the corrosion rate was three times higher in a laboratory test ${ }^{(9)}$ using refluxing but stagnant 14-molar $\mathrm{HNO}_{3}$ spiked with $25 \mu \mathrm{g} / \mathrm{g} \mathrm{F}^{-}$(as $\mathrm{HF}$ ) and $56 \mu \mathrm{g} / \mathrm{g} \mathrm{Cl}^{-}$(as $\mathrm{HCl}$ ). A titanium specimen was substituted for the titanium alloy after the processing s.ampaign and its exposure was limited to pilot plant test Runs 15-1 through 18 . Considering this, the corrosion rate was relatively high. The frosted appearance, or fluoride surface etching of the Pyrex glass specımen was more obvious (Figure 5 ) in the reboilers and product cooler sections of the system. The attack was limited to the liquid contact area of the reboiler section. There was no etching of the column.

A commercial (Teflon)-lined pipe section was installed for test evaluation as Column Section 1 (Figure 1). The steel pipe contained a nonbonded liner of 95-mil-thick FEP plastic. Inspection after process service showed no mechanical defects. However, a rust-like coating on the interior pipe wall analyzed $1.8 \mathrm{wt} \%$ nitrate, which was high enough to imply permeation of $\mathrm{HNO}_{3}$ through the liner wall.

It was concluded from these data that the process side of the reboiler should be of tantalum (as tubes or lining), the column stripping section of glass or a less-permeable Teflon liner in a metal pipe, and the column rectifying section and condenser, where fluoride levels are always low, of glass. Column packing and packing supports can be a ceramic material and the vaporizer can be Type 304L stainless steel, as in the pilot plant, since there was no severe corrosion noted. The vaporizer is subjected to less corrosive, dilute $\mathrm{HNO}_{3}$ and the aluminum nitrate media should protect it from fluoride attack.

\section{FUTURE WORK}

Laboratory investigations will be made toward defining and resolving problem areas that were evidenced in processing condensate waste. Of these, the removal of fluorides and organics is important to large-scale $\mathrm{HNO}_{3}$ recovery. More complete knowledge of condensate waste composition will be required as a starting point. There will be no further operation of the existing pilot plant. 


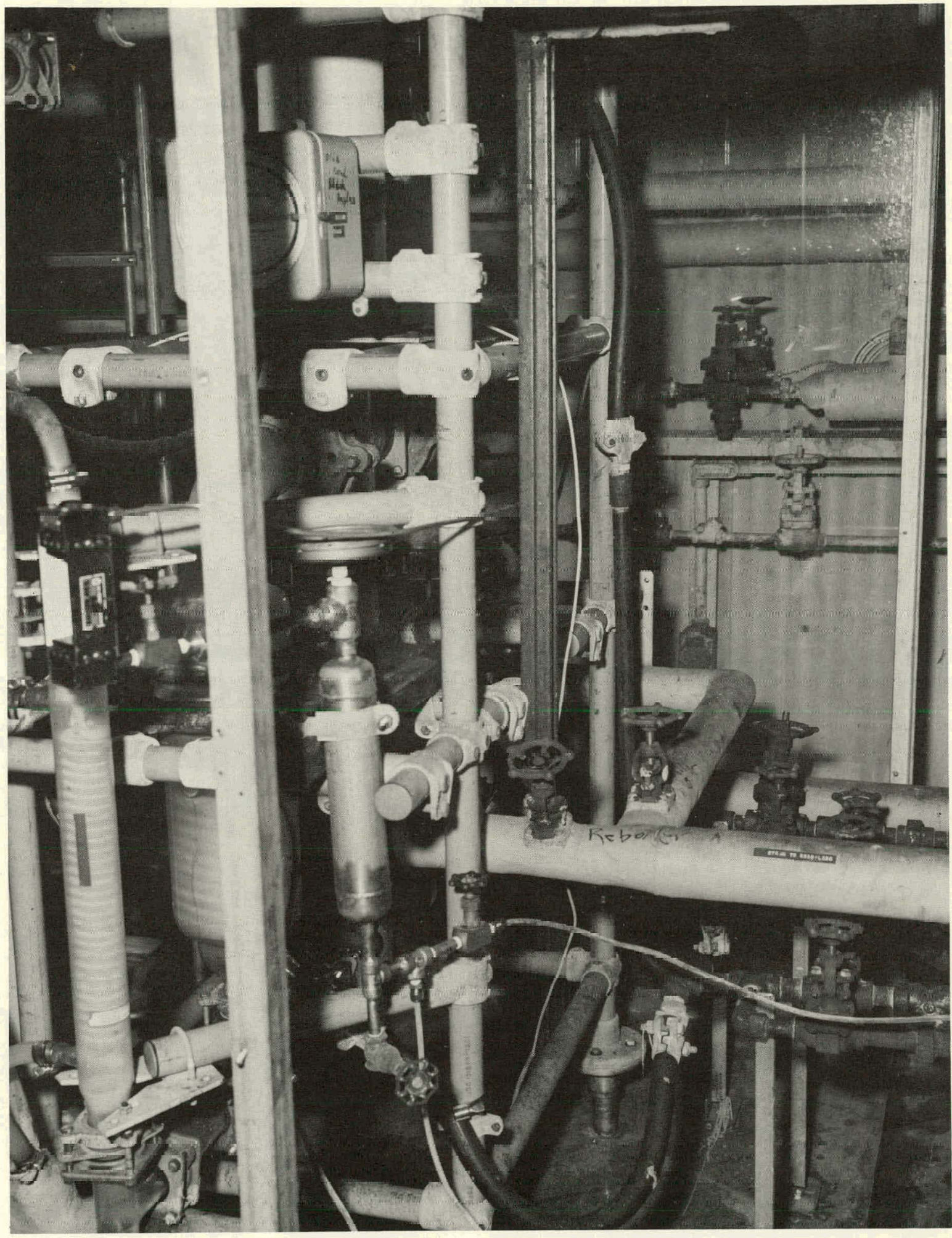

154323

Figure 5. BASE OF DISTILLATION PILOT PLANT COLUMN. (Note Frosted Appearance of the Product Cooler in Left Foreground, and the Six-Inch Reboiler Behind the Cooler) 


\section{REFERENCES}

(1) Harrington, C. D. and Ruehle, A. E.; Uranium Production Technology, p 161; D. Van Nostrand Company, New York, New York (1959).

(2) Arnold, D. S., Whitman, A., and Podlipec, F. J.; "Nitric Acid Recovery from Raffinate by Evaporation and Fractional Distillation", Chemical Engineering Progress, 52, (9), pp 362-365 (1956).

(3) Walters, F. G., Win, F. W., and Bulkowski, H. H.; The Effect of Chloride on the Design and Operation of Nitric Acid Recovery Facilities, NYO-1182; Catalytic Construction Company (1953).

(4) Braatz, R. J.; Fractional Distillation of Dilute Nitric Acid Solutions Containing Chloride and Fluoride lons, Y-B92-71; Union Carbide Corporation-Nuclear Division, Oak Ridge Y-12 Plant, Oak Ridge, Tennessee (1958).

(5) Dietrich, W. C.; Recovery of Nitric Acid from Raffinate and Condensate Solutions by Steam Distillation/Pyrohydrolysis and Fractional Distillation in a Glass Column, Y-1886; Union Carbide Corporation-Nuclear Divișinn, Dak. Ridge Y-12 Plant, Oak Ridge, Tennessee (1973).

(6) Pokela, W. U.; "Experimental Nitric Acid Concentrator", Y-12 Engineering Transmittal; October 22, 1971.

(7) Dietrich, W. C.; Personal Communication, Union Carbide Corporation-Nuclear Division, Uak Ridge Y-12 Plant, Oak Ridge, Tennessee (1973).

(8) Crooks, R. C., Wilson, R. Q., Bearse, A. E., and Filbert, R. B., Jr.; Composition of Vapors from Boiling Nitric Acid Solutions, BMI-978; Battelle Memorial Institute (1955).

(9) Jeter, I. W.; Materials of Construction - Nitric Acid Still, Y-DA-5458; Union Carbide Corporation-Nuclear Division, Oak Ridge Y-12 Plant, Oak Ridge, Tennessee (1973). 


\section{DISTRIBUTION}

Atomic Energy Commission - Oak Ridge

Hibbitts, H. W.

Hickman, H. D.

Wing, J. F.

Zachry, D. S., Jr

Los Alamos Scientific Laboratory

Rohrer, D. M.

Oak Ridge Gaseous Diffusion Plant

Hartman, W. C.

Pashley, J. H.

Wilcox, W. J., Jr

Winkel, R. A.

Oak Ridge National Laboratory

Auerbach, S. I.

Edwards, N. T.

Harris, W. F.

Oak Ridge Y-12 Plant

Abee, H. H.

Barkman, J. R.

Briscoe, O.W.

Burditt, R. B.

Burkhart, L. E./Dietrich, W. C.

Clark, F. E.

Denny, A, (100)

Francke, H. C.

Fraser, R. J.

Gary, W. E.

Isham, G. E.

Jeter, I. W.

Jordan, R. G.

Kahl, K. G./Hurst, J. S.

Keith, A.

Kite, H. T.

Laggis, E. G.

Lundin, M. I.

Marrow, G. B.
McLendon, J. D.

Mee, W. T.

Minchey, J.W.

Napier, J. M. (5)

Parsons, J. A.

Phillips, L. R.

Sanders, M.

Schreyer, J. M./Schmitt, C. R.

Smith, R. D.

Speas, I. G.

Stein, P. E.

Strohecker, J. W.

Stroud, D. D.

Weathersby, W. E.

Whitson, W. K.

Williams, R. D.

Yaggi, W. J./Googin, J. M.

Y.12 Central Files (5)

$Y-12$ Central Files (master copy)

$Y-12$ Central Files (route copy)

Y-12 Central Files (Y-12RC)

Zucker, D.

Paducah Gaseous Diffusion Plant

Baker, R. C.

Levin, R. W.

In addition, "this report is distributed in accordance with the category UC-70, Waste Management, as given in the USAEC Standard Distribution Lists for Unclassified Scientific and Technical Reports, TID-4500. 